\title{
Tres paradigmas del pensamiento español contemporáneo: trágico (Unamuno), reflexivo (Ortega) y especulativo (Zubiri)
}

\author{
PEDRO CEREZO GALÁN \\ Facultad de Filosofía \\ Universidad de Granada
}

$\mathrm{Ni}$ que decir tiene que me siento muy honrado con la invitación que me ha hecho el Instituto de Filosofia, a través de su director, el profesor Reyes Mate, de encargarme este año de 1997 de las VI Conferencias José Luis L. Aranguren, que se han convertido, pese a su corta existencia, en el foro más relcvante de la vida filosófica española. Honor doblemente acrecido, pues al prestigio y dignidad de la tribuna se une la oportunidad de reavivar la memoria de un maestro de varia y viva lección, de humanidades y de humanidad, «con quien» tanto hemos querido. Cuando me fue propuesto el tema de las mismas, Tres paradigmas del pensamiento español contemporáneo, acepté de buen grado, aun cuando no me gusta volver sobre lo hecho, en la creencia de que esta temática podría convertirse en un homenaje indirecto a José Luis L. Aranguren a través de sus maestros, y, como en un juego de resonancias, mío a él, mi maestro, de quien he aprendido, entre otras cosas, la preocupación por salvar íntegra la memoria cultural de España. Aranguren nos ha legado espléndidos estudios sobre la tradición filosófica y literaria española, y sobre todo, una magnánima actitud ante ella: comprender antes que juzgar, integrar antes que excluir, en una voluntad de mantener vivos y en diálogo creador todos sus registros. Su propio pensamiento, sin merma de influencias foráneas, se nutrió de lo más vivo y fecundo de esta tradición con una admirable libertad de espíritu, y quizá hayan de verse aquí las condiciones de su fecundidad y, en general, de toda creatividad posible: encarar la propia circunstancia, mantenerse en continuidad con una vigorosá tradición intelectual y estar en comunicación con las corrientes centrales del pensamiento contemporáneo.

Volviendo al título de estas VI Conferencias, me propongo mostrar cómo a través de la obra de estos tres pensadores, Miguel de Unamuno, José Ortega y Gasset y Xavier Zubiri, España se ha incorporado plenamente al pensamiento contemporáneo de una forma viva y creadora. Como en miniatura prodigiosa, y en el arco de treinta años, desde la raya de 1912-1914, en que aparecen los ensayos fundacionales del pensamiento español contemporáneo, Del sentimiento trágico de la vida, de Unamuno, y Meditaciones del Quijote, de Ortega, respectivamente, hasta 1944, fecha de Naturaleza, Historia, Dios, de Zubiri, 
España asume el legado filosófico de la modernidad y sienta las bases de una filosofía original autóctona. Ésta es la hazaña intelectual de estos pensadores. Lo asombroso del caso es que este intenso ciclo de pensamiento acierta a dibujar con trazos vigorosos tres paradigmas de filosofía - el trágico de Unamuno, el reflexivo de Ortega y el especulativo de Zubiri-, en brega creadora con tres nudos decisivos de la crisis interna de la modernidad. Y toda esta «gigantomaquia», por nombrarla con un viejo y bello nombre platónico, acontece por caminos trenzados internamente en una vigorosa disputa por la cosa misma. Ortega ensaya su camino de pensamiento en réplica crítica a la propuesta unamuniana, contraponiendo dialéctica a tragedia, e invirtiendo así el camino con que Unamuno había desembocado en la tragedia a resultas de la quiebra de una razón raciocinante. $\mathrm{Y}$, a su vez, con la misma interna neccsidad, a Ortega replica Zubiri con la pretensión de superar desde dentro cl límite antropológico de la metafísica de la razón vital. Explorar este denso juego de relaciones obliga a un ensayo de similitudes y diferencias, afinidades y contrastes, con el fin de resaltar en una apretada síntesis los rasgos más sobresalicntes de los respectivos paradigmas. Tal comparación no podría llevarse a cabo sin contar con un friso común de trasfondo. En los tres casos se trata de filosofias de la vida, que pretenden responder a una crisis histórica de la razón, analizada en distintos escorzos, alumbrando así una nueva praxis. De ahí que haya elegido estos rótulos como nódulos centrales de comparación. Hay, pues, una secreta conexión que enlaza, pese a sus diferencias, la idea unamuniana de existencia, la tesis orteguiana de la vida como realidad radical y la zubiriana de la inteligencia en cuanto sentir originario, como tres respuestas alternativas al problema de la vida en un tiempo de necesidad. Perseguir la lógica interna de estas réplicas alternativas es el objeto del presente trabajo, con vistas a fijar la diferencia entre sus respectivos paradigmas, que aquí sólo pueden quedar esbozados. Séame permitida una abreviatura tan intensa y esquemática, faltándome a mí la virtuosidad de aquellos miniaturistas medievales que en una vineta apresaban el gesto condensado de toda una vida.

\section{La experiencia de la crisis}

El primer nódulo al que voy a referirme tiene que ver con la crisis de la razón ilustrada, tal como se vive en Europa desde la obra de Nietzsche. Éste había encontrado uel indicio de una quiebra $(B n i c h)$, del que todos hablan como el mal orgánico original de la cultura moderna... en el miedo de la razón a sus propias consecuencias» ', cuando ésta constata sus límites constitutivos y comienza a retroceder ante la tarea de fundar el todo de la cultura.

1.1. Curiosamente, y como primera afinidad entre ellas, las tres filosofías han partido de una profunda vivencia de esta crisis. Unamuno la ha vivido

\footnotetext{
'Die Geburt der Tragödie, pr. 18 en Werke, Hanser, München, 1980, I, 102.
} 
con especial acuidad en las postrimerías del siglo $\mathrm{xIX}$, cuando el nihilismo comienza a arrojar sus primeras sombras sobre Europa. «Sentido desde cierto punto de sentimicnto - escribe en sus apuntes inéditos El mal del siglo- pocos ocasos más tristes que el de este nuestro siglo, en que a los espíritus cultos desorientados sumerge en la tristeza de su cultura misma una gran fatiga, la fatiga del racionalismo.» Se trata del malestar específico de la cultura racionalista con su civilización científico/tecnológica en el punto y hora en que el hombre comienza a percibir que tan fabulosa máquina de dominio ha traído como resultado un aplanamiento global de la existencia. Sus signos más elocuentes son, de un lado, el des-encantamiento del mundo por obra de la civilización industrial, vaciándolo de toda significación y valor, y del otro, del lado subjetivo, el desarraigo de la existencia de aquella matriz simbólica de creencias y valores en que se encontraba el humus vivificante de la vida. El fracaso no es de la ciencia - precisa Unamuno-, sino del intelectualismo. $Y$, en efecto, ha sido la reducción del espíritu a mera inteligencia analítica, instrumental y calculadora, la que ha rebajado las capacidades espirituales del hombre y cegado con ello las fuentes creadoras de toda cultura. La hipertrofia de la razón crítica no sólo destruye el horizonte significativo en que se abrevaba en otro ticmpo la vida del hombre, sino que acaba, a la postre, por fagocitarse corrosivamente a sí misma. Hacc así aparición el escepticismo tanto en la esfera de la verdad como en la del valor moral, y juntamente con ello, como su fatal resultado, la pérdida de una cultura significativa, esto es, capaz de dar sentido y finalidad a la vida, de orientar y justificar la existencia. Con la «fatiga del racionalismo» se refiere Unamuno al cansancio de esta cultura objetivista, desanimadora y desmitificadora, donde ya no queda lugar alguno para las exigencias de sentido y valor que apremian la vida del hombre. Llegado este punto se advierte con pavor que la razón es enemiga de la vida, pues contradice frontalmente sus más caras esperanzas y deja en suspenso sus cavilaciones y preguntas. Sobreviene entonces el pesimismo ontológico cuando se descubre que ya no hay razones para vivir fuera de la inercia y la costumbre. Pcro el pesimismo, como bien vio Nietzsche, es tan sólo la prefiguración del nihilismo, el gran acontecimiento de que con la muerte de Dios se ha venido abajo todo el mundo de abstracciones y valores, de falsos absolutos, que rellenan espúreamente su hueco. Lo que queda entonces no es más que la experiencia anonadadora del vacío, que Unamuno vivió dramáticamente en su crisis espiritual de 1897, documentada en su Diario íntimo.

1.2. En el análisis orteguiano de la crisis de la razón, emprendido pocos años después de que Unamuno se debatiera agónicamente con el espectro del nadismo, no se muestra con tal patetismo el carácter nihilista de la crisis, pese a los constantes registros nietzscheanos, quizá porque se ha debilitado en él, a diferencia de Unamuno, el alcance metafisico religioso del problema del sentido. Ortega pertenece a una generación plenamente secularizada, para la que la religión ha dejado de ser ya problema, reemplazada por el espíritu secular de la cultura, «socialmente más fecunda» que aquélla, pues «todo lo 
que la religión puede dar lo da la cultura más egregiamente» ${ }^{2}$. El problema está, pues, en la falta de una cultura sustantiva, capaz de ser estímulo eficaz de la vida. La crisis de la razón se interpreta no tanto en la perspectiva de una pérdida de sentido, sino de la espontaneidad creadora, propia de toda cultura genuina. El responsable de esta cultura hierática y fosilizada es de nuevo el racionalismo. Al parecer de Ortega, éste no es más que el imperialismo de la razón pura, la razón físico-matemática, surgida en el vacío de todos los intereses y motivaciones prácticas de la vida, $\mathrm{y}$, por lo mismo, censora y represora de la espontaneidad vital. Es el idealismo asfixiante y enervante en el que viera Nietzsche el rostro del nihilismo específico en la cultura científica moderna. Entre los caracteres de esta crisis destaca Ortega tres vinculados estrechamente con la condición idealista de la cultura: de un lado, el exceso de prescripción, la hipertrofia del deber o del ideal, que tanto vale, en suma, de la norma, que sofoca y reprime la espontaneidad de la vida, al socaire de educarla. Surge así una cultura venerativa e hipócrita que guarda todavía el respeto escrupuloso por lo incondicionado y puro. De otro lado, a una cultura así le falta, consecuentemente, la ilusión, que es el estímulo específico del deseo. El puro deber exige la renuncia a la ilusión para mantenerse en su idealidad incondicionada. Pero sin ilusión no es posible el aliento creativo de la vida. Una cultura incapaz de generar ilusiones se pone ipso facto de espaldas a la vida. Pero lo más grave es, con todo, la falta de veracidad o de autenticidad, de atenerse a las cosas mismas en vez de dejarse guiar por fórmulas y consignas. Pero cuando la cultura se sustantiva y autonomiza como un mundo en sí, acaba exigiendo el sacrificio de la vida ante este nuevo ídolo, cuyo culto le roba todas sus energías. Es la alienación existencial, que denuncia Ortega a partir del Tema de nuestro tiempo como especifica del culturalismo. A la altura de 1923 la crítica orteguiana a la cultura idealista arroja inequívocos acentos nietzscheanos, pasados por G. Simmel (Der Konflikt de modernen Kultur). «El culturalismo es un cristianismo sin Dios» ${ }^{3}$. El nuevo ídolo ha surgido en el vacío de la fe cristiana con la pretensión de rellenarlo con exigencias absolutas. $\mathrm{Y}$, como todo ídolo, se alimenta de las entrañas de su víctima, la vida, expropiada y mistificada al ponerse al servicio a la cultura. «Llega un momento - precisa Ortega - en que la vida misma que crea todo eso se inclina ante ello, se rinde ante su obra y se pone a su servicio» ${ }^{4}$. Éste es el yerro fundamental: creer que la cultura tiene una lógica diferente e independiente de la vida. La norma queda entonces disociada de la viviente realidad y se enfrenta a ella como un mundo aparte. Es el punto y hora de la falsificación de la vida. «La cultura se ha objetivado, se ha contrapuesto a la subjetividad que la engendró. Ob-jeto, ob-iectum, Gegenstand, significan eso: lo contrapuesto,

" «La pedagogía social como programa políticon, en Obras completas (en lo sucesivo OC) Rev. Occidente, Madrid, 1966, I, 520.

"El tema de nuestro tiempo, OC, III, 185.

${ }^{4}$ İdem, OC, 111, 172-3. 
lo que por sí mismo se afirma y se opone al sujeto como su ley, su regla, su gobierno» ${ }^{5}$. Pero nada de eso puede subsistir por largo ticmpo a cxpensas de la vida. De ahí que se atreva a vaticinar Ortega, profetizando a lo Zaratustra: «todo lo que hoy llamamos cultura, educación, civilización, tendrá que comparecer un día ante el juez infalible Dionysos" ${ }^{\circ}$. Años más tarde, en Historia como sistema (1935), vuelve de nuevo Ortega sobre la temática de la crisis, en términos que recuerdan ahora a Husserl. Como no podía ser menos, la crisis de la razón lo es conjuntamente de la vida, pues a la des-animación de la cultura racionalista corresponde la des-orientación práctica de la vida, que no sabe a qué estrellas vivir. Ortega insiste en que a esta autonomización del mundo de la cultura no ha sido ajeno el método de la abstracción idealizadora con que la ciencia ha suplantado con la red de sus abstracciones al mundo de la vida.

1.3. En cierto modo, el análisis de la crisis de la razón en Zubiri es tributario de los planteamientos de Husserl, Heidegger y Ortega, pero pronto se advierte su específica inflexión sobre el radical metafísico verdad/realidad. Al modo de Husserl entiende Zubiri que el positivismo, el pragmatismo y el historicismo, al disolver cada uno a su modo el problema de la verdad, han acarreado un desarraigo ontológico de la existencia de su único suelo nutricio: la experiencia de la realidad. Tanto el carácter técnico e instrumental de la inteligencia en el positivismo como el culto pragmatista a la utilidad o la reflexión existencial historicista han volatilizado el alcance metafísico de la verdad, reduciéndola al orden de lo meramente funcional. Pcro ni la verdad cálculo resolutivo de problemas, ni la verdad urgencia vital o acomodación al espíritu de la ćpoca pueden devolver al pensamiento su vinculación originaria con la realidad. En tales supuestos metódicos la realidad queda pulverizada en el tejido de los hechos o rebajada al de las imágenes cambiantes según las diferentes situaciones e intereses. De otro lado, la reducción de la inteligencia a mera técnica de análisis o mero reflejo ideológico coyuntural destruye el órgano único de la verdad como aprehensión de realidad. Las devastadoras consecuencias en el orden ontológico no se dejan esperar: la volatilización de la realidad, como el «humo evaporado», que al decir de Nietzsche ha dejado tras sí la idea de ser, y junto con ello, al perderse este suelo de radicación, el desarraigo de la inteligencia, que a falta de compromiso ontológico se limita a «tomar posturas». En suma, la renuncia a la verdad en el mercado de las conjeturas, imágenes y cosmovisiones. Pero sin verdad ya no es posible vida humana significativa, en cuanto que la vida exige una orientación teórica y práctica en un horizonte abierto e incondicionado conforme al télos de la verdad, esto es, de lo que es en sí y por sí la cosa misma o el asunto de pensar. Se trata, pues, de la misma vivencia de la crisis nihilista de la razón, pero que Zubiri no contempla directamente en su dimensión existencial, como había sido cl

\footnotetext{
Ibiden.

'Idem, OC, III, 178.
} 
caso de Unamuno, sino primariamente ontológica, aun cuando sin pasar por alto sus graves consecuencias existenciales. «El desarraigo de la inteligencia actual no es sino un aspecto del desarraigo de la existencia entera. Sólo to que vuelva a hacer arraigar nuevamente la existencia en su primigenia raiz puede restablecer con plenitud el ejercicio de la vida intelectual» ${ }^{7}$.

De estas tres lecturas de la crisis, tan distintas en sus claves hermenéuticas, se van a sacar conclusiones opuestas. Tras la experiencia de la oquedad de un mundo desencantado por la ciencia, tal como la vive Unamuno en el clima sombrio de la crisis de fin de siglo, va a concluir en la necesidad vital de afrontar este vacío con el ensueño creador o la fe. El fracaso de la razón analítica en orden a justificar la vida le lleva a buscar una réplica a la razón en el orden del corazón, esto es, del sentimiento y la imaginación mitopoyética, alumbrando así una cultura trágica. Pcro donde Unamuno lee fracaso de la razón tout court y de una cultura de base científico/positiva ve tan sólo Ortega el fracaso del racionalismo con su razón imperativa, sacando la conclusión, opuesta a Unamuno, de una necesaria reforma de la idea de razón que la vuclva apta para la comprensión y orientación de la vida. Cierto que esta razón vital orteguiana envuelve una nueva ontologia muy distinta y aun opuesta a la de corte eleático/platónico, pero al cabo lo decisivo es con todo para Ortega una mueva experiencia de la vida en cuanto realidad radical. Zubiri, por su parte, verá todavía en este supuesto orteguiano un índice residual de idealismo moderno, que el propio Ortega había querido combatir, y que en verdad no queda superado hasta tanto no se recupere una experiencia ontológica de la realidad, la única instancia a su juicio con virtualidad suficiente para superar el nihilismo.

\section{El sentimiento primordial}

Como acabo de señalar, la vivencia del nihilismo posibilita en cada caso un modo originario de sentir y pensar:

2.1. En Unamuno la llamada crisis religiosa de 1897 — calificación apropiada si se tiene en cuenta que se trataba para él de una crisis del sentido y finalidad de la existencia, pero que en el fondo era una crisis nihilistaprodujo un doble efecto paralelo: de un lado, una conversión existencial de su yo hacia la interioridad de las entrañas, y del otro, la relativización de todos los ideales progresistas específicos de la cultura ilustrada. En cuanto a lo primero, no hubo ciertamente, como salida de la crisis, recuperación de la fc religiosa, pero sí apertura de su conciencia al orden del corazón, hacia ese sujeto interior de resolución práctico-existencial, cuando el individuo siente el interés trascendental por el sentido y valor de su propia vida. Al modo

\footnotetext{
' Naturaleza, Historia, Dios, Editora Nacional, Madrid, 1951, p. 36.
} 
romántico, Unamuno ha hecho del corazón el centro de gravedad de la existencia. «Los grandes pensamientos vienen del corazón» ${ }^{8}$, porque, a la postre, el pensamiento no es más que la condensación de una experiencia en la forma diamantina de la idea. Del corazón brotan también las resoluciones o de-cisiones con que la voluntad abre o funda su mundo, que no es por ello su representación sino su creación. Y en el corazón, finalmente, hunde sus raíces la imaginación creadora, buscando la satisfacción de sus íntimas exigencias. El corazón, en suma, sufre, alienta y sueña. Los nuevos lugares antropológicos de esta subjetividad práctica son, por tanto, el sentimiento, la voluntad y la imaginación. Por el sentimiento obtiene el corazón el arraigo com-pasivo en la vida universal, sometida a un mismo destino de caducidad y muerte. En la voluntad, centro vital por antonomasia, experimenta el corazón su conatus o impulso por afirmarse creadoramente en el ser y constituirse como centro del universo. Y por la imaginación creadora se alumbra en el corazón la meta y el sentido de su aspiración infinita. La integridad de este nuevo sujeto es ahora conciencia en un sentido completamente diferente al intencional representativo. «Conscientia - precisa Unamuno- es conocimicnto participativo, es con-sentimiento, y consentimiento es compadecers ${ }^{9}$, esto es, compartir un mismo destino y con-sentir con la suerte del todo, y por tanto, sufrir y luchar por cl sentido final del universo. De representativa se ha vuelto la conciencia compasiva y com(b)a(c)tiva, en suma, pro-positiva de valor. En esta creación de sentido y valor, esto es, de finalidad moral, consiste para Unamuno la obra específica de la conciencia.

Conforme a este planteamiento cordial, la experiencia originaria de la vida ha de brotar, pues, de un sentimiento radical en que se siente el ser que se es, un modo de encontrarse y experimentarse en cuanto existente. Como se sabe, para Unamuno tal sentimiento es la angustia, o dicho más ceñidamente, la congoja, en cuanto el acto de existir le es revelado como el empeño o el esfuerzo por escapar a la nada. Decía antes que en la crisis nihilista se le muestra a Unamuno la oquedad del mundo. Es este vacío de ser, esto es, de sentido y valor, lo que es vivido como fondo sombrío de la existencia. Sentimiento de desesperación religiosa, lo llama en algún momento, pues en él se experimenta el abismo de vaciedad ( = vanidad) en que está sumida la vida. De ahí el ahogo espiritual con que el existente se siente ser, cercado fatalmente por el no-ser. $Y$, sin embargo, en cuanto existente no puede menos de sentirse siendo o haciendo por ser, en el acto de afirmarse en ser contra el embate de la muerte. La congoja es la agonía interior en que vive el corazón conjuntamente, como en potro de tortura, la exigencia y la deficiencia de su ser, la voluntad de no morir o el impulso a más vida junto con la vivencia de la caducidad inexorable. Dicho en términos de conciencia, el modo en

\& «El secreto de la vida», en Obras Completas (en lo sucesivo OC), Escelicer, Madrid, 1966 , III, 880 .

'Del sentimiento trägico de la vida, OC, VII, 192. 
que la voluntad creadora, compasiva y propositiva de fines y valores siente el desafio del sin-sentido y el absurdo universal, puesto que todo, también la conciencia misma, se sabe ancgado en la nada. La experiencia de existir que brota de tal sentimiento de congoja es lo que llama Unamuno ser-se, conjugando en transitivo/reflexivo el verbo ser. $\mathrm{El}$ acto de existir es ser-se o hacer por ser, per-sistir aun en medio de la agonía, resistiendo e insistiendo en ser frente a la presión anonadante del no-ser o la muerte. Ser-se es, pues, experimentarse existiendo en la tensión agónica de no-scr y sobre-ser, de des-hacimiento y per-hacimiento, como un tiempo de pasión. Y puesto que se trata de un acto de conciencia, ser-se es la voluntad creadora que pone el ser, tanto el propio como el del mundo, su sentido y su valor, contra la nada. De esta experiencia, cobrada en el curso de la crisis nihilista, brota toda la filosofía trágica de Miguel de Unamuno.

2.2. De la crisis de la razón, sin embargo, en cuanto crisis conjuntamente de la espontaneidad creadora de la vida, va a sacar Ortega una experiencia antitrágica. Se diría que para Ortega plantear el problema de la existencia en los términos agónicos en que lo hace Unamuno, como tensión entre el asalto permanente de la muerte y la voluntad de no morir, es tanto como permanecer todavía en un terreno religioso. La muerte no cuenta filosóficamente en su planteamiento. La muerte ha quedado plenamente reducida, me atrevería a decir que secularizada, como un evento meramente natural, al igual que la voluntad de no morir queda igualmente secularizada, pues no significa ya para él, en sentido trascendente, voluntad de lo eterno o infinito en el hombre sino apetito de la vida a más vida, impulso generoso de la vida a acrecerse y afirmarse. Dicho en otros términos, impulso de juego o de creatividad. Al desaparecer de la vida toda referencia trascendente, siquiera sea en la forma deficiente unamuniana de la penuria o el ansia de lo eterno, la vida se repliega sobre sí misma y gravita, por así decirlo, sobre su propio centro, en pura inmanencia. «La vida vive de su propio fondo y mana de su mismidad» ${ }^{10}$-precisa Ortega citando al maestro Eckart en un contexto ya plenamente secularizado-. No es un medio para producir valor, sino un valor en sí. La crisis de la vida, por causa de una cultura normativa idealista, estriba precisamente en la de-presión que sufre la vida, cuando se la instrumentaliza en orden a la realización de una presunta esfera autónoma de sentido. Lo religioso no escaparía a esta severa censura. A diferencia de Unamuno, el sentimiento radical orteguiano no es de congoja sino de alegría, el temple jovial del que experimenta la vida como una afirmación gozosa de su potencia y ampliación incesante de sus posibilidades. «Poca es la vida - declara en tono nietzscheano-- si no piafa en ella un afán formidable de ampliar sus fronteras. Se vive en la proporción en que se ansía vivir más. Toda obstinación en mantenernos dentro de nuestro horizonte habitual significa debilidad, deca-

\footnotetext{
"El tema de nuestro tiempo, en OC, III, 189.
} 
dencia de las energías vitales»" ". De ahí que el impulso a más vida se llame precisamente eros, el deseo que busca, que ensaya y juega por todos los caminos del mundo sin otro placer que el gozo del descubrimiento.

No ignoraba Unamuno que la nueva posición secularizadora, centrada en la herencia de la Ilustración, contradecía radicalmente sus propios planteamientos, y como siempre, aplicó una arbitraria hermenéutica de la sospecha para desenmascararla: «No puedo hacerme a la idea de que esos sujetos no cierran voluntariamente los ojos al gran problema y viven, en el fondo de una mentira, tratando de ahogar el sentimiento trágico de la vida» ${ }^{12}$. Pero el «gran problema» no era ya el problema religioso del destino eterno de la conciencia, sino el secular de una cultura laica de la tierra. Por decirlo en términos comtianos, a la edad metafísico/rcligiosa en que se encontraba todavía, trágicamente emplazada, la llamada generación del 98 , había de sucederle la edad crítico/cicntífica. En definitiva, el problema del sentido de la vida, que tan profundamente inquietaba a Unamuno, queda reducido para Ortega al problema, nada enigmático, de la determinación objetiva de las distintas esferas del valor (ciencia, moral, derecho) en el orden de la cultura. La cultura era el nuevo rostro secularizado de la religión. Evitar con todo que esta cultura se hieratice y se absolutice como una nueva religión secular, explotando a su favor el sentimiento venerativo religioso, era precisamente el problema orteguiano heredado de la crisis de la razón. Para afrontar esta tarea era indispensable enfrentarse con el tragicismo de Unamuno. $Y$ asî lo vino a reconocer Ortega en un texto tardío de 1947: «Por eso desde mis primeros escritos he opuesto a la exclusividad del sentido trágico de la vida, que Unamuno retóricamente propalaba, un sentido deportivo y festival de la existencia, que mis lectores, claro está, leían como mera frase literarias ${ }^{13}$.

En este sentimiento jovial de la vida está ya en juego una nueva experiencia de la realidad como campo abierto de posibilidades. No se trata ya del escueto enfrentamiento de la idealidad pura y la facticidad como en la congoja unamuniana, sino de asistir activamente a una realidad en trance de fermentación en el orden de lo posible. Esto es lo que llama ahora Ortega «voluntad de aventura», un nuevo tipo de querer, que lejos de intentar la hazaña heroica se demora en la circunstancia inmediata para salvarla en su sentido inmanente e inminente, en lo que puede dar de sí como su centro irradiante de significación. Frente al querer utilitario, propio del mercader, y el otro querer trascendental del esfuerzo puro por el ideal, Ortega se decanta por este querer lujoso, que por redundancia de sí mismo se dedica a la exploración de lo posible deseable. Tal querer es propiamente voluntad de creación en sentido nietzscheano; tiene algo de aquella "virtud que hace regalos" por exceso de vitalidad y poder. Esto no obsta para que Ortega utilice la expresión de ser-se para caracterizar

"La deshumanización del ante, OC, III, 367.

${ }^{12}$ Del sentimiento trágico de la vida, OC, VII, 187.

1. La idea de principio en Leibriz, en OC, VIII, 297. 
el acto del existente, que consiste en su propia obra y cuyo hacer por ser no tiene ahora el sentido del combate unamuniano contra la muerte y sus heraldos —el sin-sentido, el fracaso, el absurdo-, sino el más modesto del combate por escapar a la inercia y la presión, ensayando creadoramente la vida.

2.3. Si de este clima jovial y lúdico, tan radiante y sutilmente nietzscheano, pasamos a la obra hermética de Zubiri, cuesta percibir en ella el estremecimiento de la emoción. ¿Hay también un sentimiento originario que haya marcado, a consecuencia de la crisis, la actitud intelectual de Zubiri? Creo que sí. Zubiri se aparta tanto del estar angustiante en la realidad, al modo unamuniano, como del estar exultante del temple festivo orteguiano, a los que entiende como dos modulaciones hiperbólicas, en defecto o exceso, respectivamente, del sentimiento primordial. De un lado, su oposición a la angustia existencial no es menos fuerte que en Ortega. El privilegio de la angustia en la cultura contemporánea, desde el existencialismo, lo interpreta Zubiri como un signo inequívoco de tiempos de miseria, en los que el hombre «va perdiendo, de una manera alarmante, el sentido de su realidad» ${ }^{14}$, y con ello, de la realidad en cuanto tal. Al angustiado le falta ser o siente la penuria de su ser. De ahí la inquictud incesante, la intensa preocupación por un porvenir que no está en su mano, la ansiedad por un tiempo que falto de asiento se escurre como la arena. Éstos son los signos de una impotencia radical, pues «la angustia es una primaria y radical desmoralización» ${ }^{15}$. Para Zubiri, la impotencia del alma angustiada se debe a haber perdido su confianza en el poder de la realidad, que nos asiste. Pero esta confianza no se gana con la mera intensificación de la voluntad de vivir; antes bien, ésta puede precipitar, por contraste, una experiencia aún más honda de penuria. La voluntad radical, señala certeramente Zubiri, «no es voluntad de vivir, sino de ser real» ${ }^{16}$. No basta con la exploración de lo posible si no hay una voluntad apropiadora de las posibilidades según su valor intrinseco de realidad. Y esta primaria experiencia de la realidad se da precisamente en el sentimiento, «El modo de estar acomodado tónicamente a la realidad es aquello en que consiste formalmente el sentimiento ${ }^{17}$. Pero cualquiera que sea en concreto ese modo en las diversas circunstancias y situaciones de la vida, hay un temple de ánimo fundamental de estar en realidad en cuanto realidad, de sentir su temperie. Es el sentimiento estético originario de que la realidad nos asiste con su poder atemperante. Atemperado en y por la realidad, el hombre se siente fundado y acogido en ella, y por lo mismo, moderado, esto es, tonificado y templado por su poder. Puesto que la crisis de la razón significa para Zubiri, en términos nihilistas, el desarraigo ontológico de la existencia, sólo del sentimiento primordial de estar-en realidad

14 Sobre el sentimiento y la volictón, Alianza Editorial, Madrid, 1991, p. 80.

15. Idem, 400 .

"El hombre y Dios, Alianza Editorial, Madrid, 1988, p. 106.

${ }^{17}$ Sobre el sentimiento y la volición, op. cit., 335 . 
y contar con su poder fundante y atemperante puede esperarse, a su juicio, la superación del nihilismo. La experiencia que brota de tal sentimiento es entender la existencia como un acto de autorrealización de la vida según la altura ontológica de las posibilidades puestas en juego. No voluntad de poder, del propio poder, erigido en medida de lo real, al modo nietzscheano, sino voluntad de verdad ( = de realidad), que en última instancia no es más que la libre disposición del amor.

\section{La nueva experiencia de la vida}

Conviene registrar ahora, de nucvo en términos diferenciales, la experiencia ontológica que surge respectivamente en cada caso de la correspondiente actitud.

3.1. Para Unamuno se trata de una experiencia pática, esto es, no objetiva ni reflexiva, del acto de existir ( = sum), en una autocomprensión hermenéutica de lo inmediatamente vivido. Decía que tal acto es ser-se o hacer por ser, cobrando conciencia de que se es en tanto que se obra o se está empeñado en la obra de sí. El sujeto de tal acto es, pues, el yo concreto, que se siente inmediata y absolutamente concernido, puesto que le va su ser. Es el «hombre de carne $y$ hueso, el que nace, sufre y muere, sobre todo muere» ${ }^{18}$-precisa Unamuno-, pues es la muerte, el ser para la muerte, lo que le despierta la conciencia de sí. Se trata, pues, del yo en posición efectiva de finitud, sujeto al ceñidor de la necesidad, vinculado a un cuerpo, más aún, identificado con su ser carnal, sensible y sufriente, y cargando con la facticidad de un aquî y un ahora, un espacio/tiempo que lo constituye en la integridad de su ser. Esta es la subjetividad real efectiva en directa oposición al yo/conciencia del idealismo. Es, pues, este yo, en su concreción y determinación, un individuo único e intransferible, distinto a todos los demás y contrapuesto al todo por el límite de su individuación. Pero, a la vez, este yo finito vive en tensión de infinitud, abierto a una totalidad de la que carece pero a la que se encuentra intrínsecamente referido. Esto es propiamente lo que significa la voluntad de no morir, el impulso a trascender la propia limitación y abrirse a lo absoluto e incondicionado, realizándose como conciencia universal e integral. Resulta indudable la filiación cristiana de esta experiencia ontológica: el yo finito no sólo se delimita por contraposición a lo infinito, a lo perfecto y absoluto, sino en tensión de infinitud, como un movimiento de autotrascendencia. La voluntad de no morir es, pues, deseo de lo infinito - no ya simplemente idea de lo infinito, como en Descartes-, sino exigencia de lo infinito, en tensión creadora hacia él, una aspiración trascendental de la conciencia, pues no hay conciencia sin sentido ni sentido sin finalidad ni finalidad cabal sin la garantía del triunfo definitivo sobre el sin-sentido y la muerte. Dicho en otros términos, no es,

${ }^{1 *}$ Del sentimiento trágico de la vida, OC, VII, 109. 
pues, idea de Dios al modo cartesiano, sino necesidad de Dios en el seno mismo del acto de existir, en tanto que empeño de conciencia, esto es, de sentido y valor, contra la muerte. $Y$ en esta neccsidad, cl propio empeño por ser o afirmarse como conciencia es ya, aun en medio de la penuria, una experiencia de lo eterno en el hombre.

Esta tensión de infinitud en que se encuentra constitutivamente el yo finito permite comprender la integridad de su condición: que el dolor sea el testimonio irrefutable de su conciencia; que cl conatus o el esfuerzo exprese la realidad de su acto; que la elección de sí sea el núcleo diamantino de su libcrtad. Ante todo, la conciencia de sí se revela como dolor de existir en esta tensión agónica. Ya Hegel había advertido que el dolor es el privilegio de los seres vivos, en cuanto llevan en sí la vida universal como negativo de su propia singularidad, y experimentan en sí esta contradicción. Y casi como cn eco directo advierte Unamuno que «el dolor universal es la congoja de todo por ser todo lo demás sin poder conseguirlo, de ser cada uno lo que es, siendo a la vez todo lo que no es, y siéndolo por siempre» ${ }^{19}$. De ahí que el dolor sea la misma pulsación de la conciencia de sí, la experiencia del conflicto ontológico entre muerte y vida, desfallecimiento y florecimiento, limitación y plenitud, que, según Unamuno, constituye al existente. Dolor por la limitación y la penuria ontológica, pero también por la aspiración hacia lo que faita. «Dolor de la congoja, de la congoja de sobrevivir y ser eternos» ${ }^{20}$. Dolor compasivo, pues al sentir la propia nadería se compadece uno de la miseria universal, pero no menos dolor creativo, ya que reenciende cl deseo de salvar todo lo que sufre por el embate de la muerte. El dolor, a su vez, expresa la tensión del conatus o del esfuerzo por ser, que no es ya el principio de la inercia sino de la perficiencia ontológica. En este sentido, Unamuno interpreta el conatus de Spinoza desde la voluntas de Schopenhauer, a la que, a su vez, personaliza como obra de conciencia. El conatus es, pues, apetito de divinidad, en tanto que en él se expresa una conciencia compasiva y propositiva que aspirando a lo eterno resiste creadoramente el asalto de la muerte. Ahora bien, en tanto que conatus de un ser libre, esto es, no voluntad ciega sino vidente o pro-vidente, el impulso a ser se esfuerza por realizar en el tiempo una idea arquetípica del yo, el yo eterno, donde reside para cada uno su propia medida de humanidad, su secreto y vocación. De esta manera, la experiencia existencial de Unamuno, a travếs de Schopenhaucr, se abria al idealismo moral kantiano, a la voluntad de creación del yo nouménico o moral sobre el fenoménico contingente.

3.2. Si volvemos ahora la mirada hacia Ortega se percibe inmediatamente su oposición a una filosofía idealista y moral de la praxis, al modo unamuniano, en función de una concepción de signo experimentalista. Su sentido jovial de la vida implica obviamente una nueva experiencia de la realidad completamente

If Lem, OC, VII, 232.

Nidem. 
distinta al tragicismo existencial unamuniano. Se trata de un sentido primordial de experiencia como vida experimentadora del mundo. En cuanto tal, es una vida prerreflexiva, esto es, anterior a la autoconciencia objetivadora, y por lo mismo, pre-lógica, pues no está aún decantada en categorías universales. "Vida individual, lo inmediato, la circunstancia son diversos nombres para una misma cosa: aquellas porciones de la vida de que no ha sído extraído todavía el espíritu que encierran, su logos» ${ }^{21}$. En su intento de oponerse al cartesianismo, Ortega retrocede, pues, a un nivel originario de cxpericncia, específico del yo ejecutivo - "cogito viviente» lo llama Husserl- en su compromiso concreto e inmediato con el mundo. Ciertamente hay en juego una intencionalidad, pero no reflexiva sino operativa, práctico/vital, conforme a los intereses que inspiran las tareas y metas de la vida inmediata. La realidad no está dada por modo de objetivación sino de participación pática y ejecutiva en las cosas o acontecimientos, que son por ello primariamente cosas de la vida. En este sentido primario, vivir es habérselas con las cosas en la circunstancia o el mundo inmediato en derredor, tratar y familiarizarse con ellas, $y$, por tanto, hacerse cargo de su sentido, que no es otro que el que presentan en función de aquellas dimensiones prácticas de la vida, a las que conciernen. El yo individual experimenta el mundo, y conjuntamente se experimenta en la amplitud y profundidad de su poder como vida animadora del mundo. Se trata, pues, del «mundo de la vida», en la acepción que le da Husserl, como mundo predado, y siempre presupuesto, campo y suelo de toda experiencia posible. Claro está que esta vida inmediata, para dar de sí en plenitud, tiene que estar mediada o filtrada por el universo de la cultura.

Más tarde desarrolla Ortega este concepto fenomenológico de vida como «ser-en-el-mundo» mcdiantc diferentes esquemas hermenéuticos. Bajo la influencia de Nietzsche, y en abierta oposición a Azorín, que había subrayado el peso de la costumbre como argamasa de la vida cotidiana, Ortega la entiende como experimento creativo, en que el hombre se pone a prueba en la envergadura de su poder. «Y esto debe ser la vida de cada cual: a la vez un armonioso espectáculo y un valiente experimento» ${ }^{22}$. El experimento supone ensayo programado para la exploración tanto de las virtualidades de lo real como de las posibilidades del hombre. No se trata, sin embargo, de un programa tentativo y reactivo sino de una manifestación de la energía creadora, del apetito a más vivir, que lleva a la vida a la invención de nuevas formas y a la experimentación continua de sí misma. En la puesta en juego de tales posibilidades la vida se expresa simbólicamente a sí misma, a la vez que abre o constituye el horizonte de sentido del mundo. Y, junto a la dimensión experimental creativa, la reflexiva del espectáculo, de verse, contemplarse y modelarse como una viviente obra de arte. A su vez, frente a Baroja y a diferencia de su degradación de la aventura en una acción carente de motivación y propósito, reclama

\footnotetext{
" Meditaciones del Quijote, OC, I, 320 ,

22 "Azorín, primores de lo vulgar», OC, II, 162.
} 
Ortega el sentido creativo de la aventura como realización de un proyecto o programa de vida. Por último, en oposición a la hazaña heroica, que constituía el paradigma existencial de Unamuno, reivindica Ortega el espíritu nietzscheano del jucgo, como el verdadero régimen de la libertad y la creatividad. El juego se produce más allá del reino de la necesidad, donde sólo pueden darse conductas reactivas. No hay en él ni la teleolología del homo faber ni la otra teleología trascendental del homo culturalis, pendiente de la realización del valor moral. En el juego la vida se expresa en la superabundancia de su poder, y proyecta desde sí y por sí las metas de su acción, sin otra finalidad que el despliegue y goce de su propia potencia. Es el juego como arte o el arte/juego, que hace de la vida una obra de imaginación creadora y de autoplasmación formativa. No la vida agónica, al modo unamuniano, sino la agonal deportiva, del que expone la vida al margen de la utilidad o el valor moral, y no rehuye el riesgo ni el esfuerzo puro, en cuanto exponentes de la generosidad vital con que la vida se entrega a sí misma. Años más tarde, cuando retrocede en la obra orteguiana la influencia de Nietzsche y crece paralelamente la de Heidegger y Dilthey, Ortega se complace en destacar el aspecto dramático de la vida humana en cuanto afronte de la circunstancia con vistas a la realización del proyecto de ser. Subraya entonces la vieja intuición cervantina de la vida como naufragio, como ex-posición y permanente estar en peligro, en trance continuo de perderse o ganarse como «sí mismo» en una forma original y propia de existencia. No tiene un ser dado, tiene que serlo y, por tanto, inventarlo y realizarlo en el afronte creativo con su circunstancia. La vida es constitutivamente problema, problema de sí, cn un medio extraño y fácticamente dado, la circunstancia, y por lo mismo, inexorable quehacer o cmpresa de sí, teniendo que hacer irremediablemente la figura del propio ser.

La praxis vital que surge de este programa se resume en el lema orteguiano «salvar la circunstancia», ya que «si no la salvo a ella no me salvo yo» ${ }^{23}$. A una, pues, se juega el destino del yo y el de su mundo, pues la salvación los afecta a entrambos de consuno. Desde el primer momento entendió Ortega su obra como una tarea de «salvaciones» en el sentido renacentista del término. En un apunte de trabajo precisa al respecto: «El estilo de Cervantes es el mismo que el de mis salvaciones: salvar el presente.» Lo que entendía por tal tarea queda explícito en sus Meditaciones del Quijote, urgidas por la necesidad de arrojar luz sobre su tiempo y circunstancia inmediata y hacer experimentos de nueva España, poniendo a ésta en la forma intelectual de Europa. Pero lo que era su personal destino como pensador se le reveló como la tarea humana por excelencia. «En suma, la reabsorción de la circunstancia es el destino concreto del hombre» ${ }^{24}$. Reabsorber es un término de vaga evocación dialéctica, en el sentido de superar integrando la propia circunstancia, abriéndola e insertándola en el mundo del scntido. Salvar la circunstancia es tanto

${ }^{23}$ Meditaciones del Quijote, OC, I, 322.

Ibidem. 
como llevarla, por el camino más corto, «a la plenitud del significado», que hay en ella de modo insurgente o inminente. No dejarla en su nuda inmediatez, sino elevarla reflexivamente al orden de la idea, conectándola así con los grandes temas y procupaciones del espíritu humano. Sólo entonces, al refractarse en el espejo bruñido de la conciencia, la cosa se ilumina en «innumerables reverberaciones». Pero no basta con iluminarla en su sentido. La reabsorción implica, en segundo lugar, apropiarse de la circunstancia en una tarea de libertad, haciendo de ella un punto de asiento de la propia vida. De ahí que la salvación de la cosa en su sentido sea también una salvación del yo. Salvarla es salvarse. Se trata de un mismo movimiento de salvación contabilizado por partida doble, pues al alcanzar el sentido inmanente de la circunstancia se transforma también el sujeto de la misma - el yo espontáneo-en un yo reflexivo, mediado por la cosa misma de la experiencia. Salvación, pues, no de las cosas, al modo idealista, como si éstas tuvieran que ser negadas desde un reino de pura idealidad, sino en las cosas mismas, en virtud de la norma objetiva que anida en ellas. Muy tempranamente, y de nuevo en batalla con Miguel de Unamuno, había lanzado Ortega su consigna de «isalvémonos en las cosas!» ${ }^{25}$ como única alternativa a la polémica que ocupaba la plaza pública española. Reclamaba con ello un régimen de objetividad capaz de devolver a los españoles la disciplina del concepto. Esta salvación suponía tanto la superación del yo subjetivo y caprichoso como la conquista del yo genérico de la praxis racional. Este era el programa orteguiano para la salvación de su presente, a la altura de la segunda década del siglo, cuando el encuentro con la Fenomcnología marcó un nuevo rumbo en la orientación de su pensamiento, apartándolo del trascendentalismo neokantiano.

3.3. Desde este planteamiento se entiende el primer interés zubiriano por la Fenomenología y su nuevo régimen de objetividad, todavía bajo el influjo de su maestro Ortega y Gasset. Pero pronto advirtió, quizá por el impulso mismo con que Ortega se esforzaba por superar el idealismo fenomenológico husserliano, que para ello no bastaba la exigencia del objetivismo si éste no tenia un fundamento ontológico en la cosa misma. La crisis de la razón de que había partido requería una respuesta más radical. Ésta ponía ciertamente de manifiesto ala urgente necesidad de la reconquista de este sentido del objeto... (Pero) no se trata de una mera reconquista, sino de un replanteamiento radical del problema con los ojos limpios y la mirada libre» ${ }^{26}$. El salvarse objetivamente en la cosa equivalía para él primariamente a salvar la cosa en la realidad; no simplemente la cosa/objeto, sino en su real estructura de ser. Pero de este modo también se salvaba el yo en tanto que subjetividad real. «Asi como el hombre siente lo real se siente también a sí mismo en su verdadero y real ser» ${ }^{27}$. A una, pues, acontcce para el hombre el radicarse en realidad

¿ «Unamuno y Europa, fábula», OC, I, 131-2.

* Naturaleza, Itistoria, Dios, op. cit., p. 35.

${ }^{27}$ Idem, 63 . 
y el abrirse a la propia realidad. Sentir-se real es consecutivo a sentir lo real en cuanto tal. Fuera de este centro de radicación sólo caben posturas subjetivas pero no experiencias de realidad. Ciertamente Ortega había entendido la vida como un habérselas con las cosas, y es muy posible que una fórmula tan sugestiva atrajese desde el primer momento la atención de Zubiri. Pero si bien se observa, tal haber tenía primariamente en Ortega un sentido práctico según los intereses y tareas que priman en el mundo de la vida. La cuestión es saber dónde radica este habérselas con, que para Zubiri implica un previo estar en realidad. En otros términos, para habérselas realmente con las cosas hay que tratarlas según o conforme a su propio haber, a lo que ellas son, y, por tanto, estar previamente en realidad con ellas. Este «estar-en» es, por lo demás, la determinación más radical y propia del hombre. De este empeño por una restauración metafísica surgió, pues, la filosofía original de Zubiri.

Tal propósito lo obligaba a una experiencia ontológica cuya clave creyó hallarla en el fino realismo sensualista de Aristóteles. Experimentar, lejos de cualquier tentación constructivista neokantiana e incluso descriptivista fenomenológica, significa primariamente sentir realidad. «La experiencia es el lugar natural de la realidad» ${ }^{28}$. Pero no basta con decir que este lugar natural es el mundo de la vida si previamente no se ha determinado la constitución ontológica de este lugar como apertura a la realidad en cuanto tal. «El ser es siempre ser de lo que hay. $\mathrm{Y}$ este haber se constituye en la radical apertura en que el hombre está abierto a las cosas y se encuentra con ellas» ${ }^{29}$. La experiencia es, pues, de la cosas, pero se da en realidad. Tal dar-se constituye la posibilitación trascendental de la experiencia. «Hay experiencias de cosas reales - escribe en 1935 - , pero la realidad misma no es objeto de experiencia. Es algo más: la realidad, en cierto modo, se es; se es, en la medida en que ser es estar abierto a las cosas» ${ }^{30}$. Sólo en esta apertura ontológica - lo que Heidegger a su modo había designado con la expresión Da-sein- - está fundada o radicada la experiencia. Ésta es ciertamente el lugar primario de toda manifestación o patencia de la cosas para el hombre, pero sólo si es el lugar de la realidad. En un primer tiempo la determinación de este lugar guarda todavía acentos orteguianos. «Las cosas están situadas, primariamente, en ese sedimento de realidad llamado experiencia a título de posibilidades ofrecidas al hombre para existir» ${ }^{31}$. Ciertamente se trata de un sentido vital o existencial de experiencia, pero con tal de que se entienda que la posibilidad primaria y constitutiva de cualquier otra es la propia condición ontológica de lo real. Sólo la realidad es el fundamento de la posibilidad. Había, pucs, que liberar el concepto de experiencia de las connotaciones meramente pragmáticas. Tengo la sospecha de que a Zubiri la idea orteguiana de experiencia le parecería demasiado antro-

idem, 154 .

29 idem, 346 .

* Idem, 344.

"Idem, 157. 
pologista, muy cortada al talle de los intereses inmediatos y primarios del hombre. Pero hay algo previo a toda posible efectuación concreta de interés que es el interés trascendental de y por la realidad. Era preciso, pues, ir por detrás de la experiencia, entendida al modo práctico vitalista, hacia la cosa en sí o la cosa en su mismidad. «La cosa misma: ésta es la cuestión... En la expresión el vino mismo, el "mismo" significa esta cosa real. La cosa misma es la cosa en su realidad» ${ }^{32}$. La experiencia era así el origen único del «saber lo que una cosa es, saber a qué atenernos, en punto a lo que ella es y no sólo a lo que parece» ${ }^{33}$. A esta experiencia originaria la llamó el griego nous, traducido más tarde como mens, un sentido de palpo mental o de sentido del ser, como un probar, gustar sabrosamente la cosa en su ser. La cxperiencia es para Aristóteles la progresiva decantación o estilización del sentido de la cosa. «Sentido - precisa Zubiri - no es aquí una significación sino el sentido del sentir mental. El nous, la mens, es el sentido mismo puesto en claro, e inversamente, esta claridad lo es de un sentido ${ }^{34}$. Sentir entendiendo $o$ cntender sintiendo será, pues, el acto fundante o posibilitante de toda experiencia. Es la primera indicación de lo que será su teoría madura de la inteligencia sentiente.

A este sentir originario lo llamó Zubiri impresión de realidad. «La realidad no es algo entendido sino algo sentido: la formalidad del "de suyo" como propia de lo inteligido en y por sí mismo con anterioridad a su estar impresivamente presente» ${ }^{35}$. No se trata, sin embargo, de una impresión específica y aparte de las de los sentidos, sino de un nuevo modo de sentir que envuelve y penetra cualquier dato sensitivo, un modo de darse lo sentido o de quedar en la aprehensión como «de suyo», esto es, remitiendo a sí mismo, a lo que es propio y no a su mero valor orgánico funcional. El «de suyo» se opone al «para mi» de la mera afección animal estimulante. Es sentido como real lo que ha dejado de ser sentido como no más que estímulo, para reclamar la atención, con independencia de su valor orgánico/funcional, a lo que en verdad es. Su carácter de real no es un nuevo contenido sino la formalidad en que queda el contenido sentido, remitiendo a sí, a lo que de suyo es y con anterioridad es. Según Zubiri, en la impresión de realidad se hace presente lo sentido con una fuerza de imposición incontestable. Es una presencia efectiva de sí y por sí, como siendo con anterioridad a la impresión misma. Ese prius es aquí decisivo. Obviamente no tiene un carácter temporal sino ontológico. «El prius - -aclara Zubiri- - es un momento intrínseco de la presentación misma; es el modo mismo del presentarse» ${ }^{36}$. No es que lo real sea antes de la aprehensión, sino que es trascendiendo a su presentación, en cuanto se actualiza

\footnotetext{
Idem, 55

I I Iem, 47.

34 Fom, 61.

${ }^{3}$ Inteligencia sentiente, Alianza Editorial, Madrid, 1980, p. 218.

36 Sobre la esencia, Sociedad de Estudios y Publicaciones, Madrid, 1962, p. 417.
} 
o hace presente en ella en virtud de sí mismo. Este trascender lo presentado no implica, sin embargo, un ser trascendente, allende la impresión, sino un remitir a lo que es de suyo con independencia de ser aprehendido. El forcejeo semántico del análisis zubiriano pretende situarnos más allá del dilema inmanencia o trascendencia en que se había empantanado históricamente la cuestión de la realidad. O lo sentido - -se creía - está meramente dentro, como dato subjetivo, o está meramente fuera, allende la impresión, como algo en sí trascendente, tal como se aparece. Pero este dilema conlleva un doble dogmatismo: O esse est percipi como defiende el idealismo fenomenista, o percipere est percipere id quod est quatenus in se est, como asegura el realismo dogmático. A un ingenuo realismo se le replica con un idealismo igualmente ingenuo, según la lógica dilemática de que o se tiene la cosa en sí o sólo queda un fenómeno subjetivo. La apertura como trasdendencia, advierte Zubiri, no es un estar ya en lo trascendente, sino algo previo y muy distinto: un estar ya en la realidad, en cuanto formalidad abierta, trascendiéndose hacia lo que ésta sea o pudiera ser en sí misma. El ya y el hacia no implican coordenadas temporales sino dimensiones ontológicas de la apertura como un estar instante y dinámico. Se comprende entonces que estar-en-realidad no pueda ser interpretado como un mero estar intencional o representativo, sino como un efectivo radicar de la mente en la actualidad de lo real. La inteligencia queda remitida al haber de la cosa, retenida en ella por su propia fuerza de imposición. Más que un aprehender o un coger, en que hubiese una anticipación activa del sujeto, es un ser cogido, captado en y por la actualidad de lo que se presenta; un ser atrapado al modo como decimos, por hablar metafóricamente, que el cuerpo es atrapado por la fucrza de gravedad. Se diría que la inteligencia gravita sobre la cosa, tiene en ella su centro de gravedad y queda ella misma actualizada en el ergon o poder manifestativo de la realidad. Es la luz irradiante de la cosa la que se le hace presente o por la que puede ver. Queda, por así decirlo, como traspasada por su luz. El haber de la realidad es así el fundamento de la inteligencia, porque hay realidad, y en tanto que la realidad actualiza su haber en la inteligencia, la inteligencia es o está en acto de su ser. En cuanto «lugar de la realidad» no es más que el medio de su actualización. Se alumbra de este modo un concepto ontológico de vida como sentirse y actuarse en ser, vida como autorrealización en y por la realidad. A este sentido dinámico se refiere Zubiri cuando indica que la impresión de realidad no es noesis sino noergia, es decir, no se trata de una correlación trascendental sujeto/objeto como la propia de la conciencia husserliana, sino de su respectividad en un mismo acto, de una acción conjunta de coactualización: la realidad haciéndose presente en la inteligencia y actualizándose en ella como de suyo, y la inteligencia teniéndola presente o manteniéndola en su propia actualidad. Esta presencia no es, sin embargo, ni mera presentidad impresiva, al modo empirista, ni pre-sentificación al modo idealista, sino un dar-se la realidad, remitiendo a sí misma en el acto mismo de la inteligencia. De ahí que la inteligencia sea vida - retoma 
Zubiri la tesis aristotélica-, esto es, presencia instante y dinámica, ser cabe sí estando a la vez abierto a lo otro.

Es obvio que esta experiencia ontológica no puede estar exenta cn modo alguno de alcance praxeológico, si se toma el término praxis en la acepción originaria de su significado como acción inmanente transformadora. A ésta la entiende Zubiri como apropiación de las posibilidades de lo real por parte del hombre. Pero tal apropiación, cualquiera que sea el sentido en que se la entienda, implica siempre y necesariamente, como su condición misma de posibilidad, la «posesión esciente de la realidad. Fuera de la (expericncia de la) realidad todo se hace espectral y evanescente. La vida humana se consume por asfixia ontológica, faltándole posibilidades, porque no le asiste la realidad.

\section{Los paradigmas ontológicos}

Desde los presupuestos hasta aquí desarrollados estamos en condiciones de abordar el punto central de comparación entre los respectivos paradigmas de filosofía. Unamuno ha calificado al suyo de trágico. No sólo sentimiento trágico - la congoja-, sino actitud trágica - la duda de pasión-, y cosmovisión trágica del mundo ante la imposibilidad de conciliar «las necesidades intelcctuales con las necesidades afectivas y volitivas ${ }^{37}$.

4.1. El paradigma trágico: Lo común a estos distintos usos del adjetivo «trágico» es la idea de agonía en el sentido fuerte de lucha contra la muerte. «Y la tragedia es perpetua lucha sin victoria ni esperanza de ella; es contradicción» ${ }^{28}$. En lo trágico se da a la vez, paradójicamente, la vivencia de la impotencia (no poder escapar, no poder escamotear, no poder conciliar) y la de la fuerza (no renunciar, no dimitir, resistir). «Wer spricht vom Siegen? Ueberstehen ist alles» - había cantado Rilke-. En suma, se trata de la experiencia de lo «imposible necesario», de la puesta en juego de una exigencia vitalmente neccsaria, pero de imposible cumplimiento o satisfacción. De ahí la contradición existencial en el afronte permanente de dimensiones inesquivables e incompatibles. En lo trágico moderno, a diferencia de la tragedia antigua, el conflicto se ha internalizado en el seno mismo de la existencia. No es ya la lucha de la voluntad titánica contra el destino inapelable, sino la lucha intestina o guerra civil, como solía decir Unamuno, entre instancias exclusivas y excluyentes, en el seno del mixto demoníaco que es el hombre, intermedio, como ya vieron Descartes y Pascal, entre lo finito e infinito. Debemos a Hegel la penetrạnte intuición de que la tragedia consiste en una colisión de fuerzas dotadas de significación positiva, en la medida en que cada una tiene su propio derecho. Esta idea ha guiado el análisis fenomenológico que ha dedicado Max Scheler a la esencia de lo trágico como un conflicto que

${ }^{37}$ Del sentimiento tragico de la vida, OC, VII, 118.

3 Hater, 117. 
concierne a la libertad, en tanto que pone en juego relaciones de valor (Wertbeziehungen) antagónicas y excluyentes entre las que no cabe conciliación posible. Más, pues, que de contradicción (Widerspruch) habría que hablar de oposición (Widerstreit), en la que cada contrario se afirma resistiendo a su antagonista, apoyándose en él, como en la imagen unamuniana del abrazo trágico, y recibiendo del otro, en el contragolpe, un impulso de reafirmación. Y es que la tragedia en Unamuno debe más al estilo kantiano de las antítesis que al dialéctico hegeliano. Porque aquí se trata de una contradicción sin mediación posible ni superación del antagonismo. Inversa y complementariamente al juicio de Nietszche de que la dialéctica socrática supuso el fin de la tragedia antigua, cabe aguardar una vuclta necesaria de la tragedia, como al desquite, cuando se desespera del poder de la razón para resolver las antinomias. Creo que con todo derecho se puede tomar el texto kantiano de la tercera antinomia de la razón pura como el acta originaria de la conciencia trágica moderna. $Y$ es muy significativo a ese respecto que Max Scheler, aun sin mencionarlo, lo tenga a la vista cuando define el conflicto trágico dcl modo más preciso y riguroso: «el lugar de lo trágico -escribe-, el lugar de su aparición no se encuentra ni en las solas relaciones de valor ni en la relación de acontecimientos y fuerzas causales que las portan, sino en una singular conexión de relaciones de valor con relaciones de causa» ${ }^{39}$. Finalidad y mecanicismo, o dicho en otros términos, el orden valorativo del corazón y el orden causal explicativo de la razón entran en una colisión insuperable. Lo que para uno es todo para la otra es nada; donde uno encuentra sentido sólo ve la otra sin-sentido y absurdo, y recíprocamente, el mundo objetivo de la razón está vacío para las exigencias del sentimiento. Muy agudamente ha caracterizado L. Goldmann la tensión trágica como «el movimiento perpetuo entre los polos del ser y de la nada, de la presencia y la ausencia, movimiento que, sin embargo, no avanza jamás, porque, eterno e instantáneo, es extraño al tiempo donde hay progresos y retrocesos» ${ }^{40}$. El alma trágica vive crucilicada en el instante atemporal de una tensión, que no admite resolución ni salida. El perpetuum mobile la mantiene en agitación permanente, oscilando pendularmente de lo uno a lo otro. «El conflicto es irrcconciliable» ${ }^{4 i}$-precisa Unamuno-. No hay, pues, dialéctica sino agonía, una lucha interna entre opuestos entre los que no cabe mediación. Guerra intestina, como acabo de decir, cntre corazón y razón, y a su través, entre los dos polos ontológicos que representan respectivamente: la voluntad de no morir, de trascenderse, y el destino de caducidad y muerte. No es un conflicto meramente psicológico. Cuando Unamuno habla de voluntad de no morir se refiere al faktum originario del impulso a más vida, que forma la esencia misma de la voluntad. No es sólo la exigencia de

39 «Zum Phänomen des Tragischen», en Gesammelte Werke, Francke, München, 1972, III, 159.

${ }^{4 y}$ El hombre y lo absoluto, trad. esp. de Dieu caché, Península, Barcelona, 1968, p. 95.

${ }^{41}$ Del sentimiento trágico de la vida, OC, VII, 183. 
lo incondicionado o absoluto, sino el impulso activo a una afirmación en ser, que no sabe de la muerte. Por el contrario, la razón sabe de la muerte, pues no se le oculta el límite temporal y espacial infraqueable de todo lo finito y limitado. «La paz entre estas dos potencias se hace imposible y hay que vivir de su guerra. Y hacer de ésta, de la guerra misma, condición de nuestra vida espiritual» ${ }^{42}$.

¿Es esto posible o la tensión trágica es de suyo improductiva? Esta es la cuestión para Unamuno. «De este abismo de desesperación puede surgir esperanza, y cómo puede ser fuente de acción y de labor humana, hondamente humana, y de solidaridad y hasta de progreso, esta posición crítica» ${ }^{43}$. Lo del «abismo de desesperación» no es una figura retórica. La desesperación es el modo en que se tocan y funden los antagonistas en el abrazo trágico. Casi podría decirse que es el modo patético de su reflexión. El corazón se vuelve desesperado ante el asalto de la razón, en el mismo movimiento en que la razón se reconoce escéptica cuando afila su crítica contra las pretensiones del corazón. El corazón deja de ser dogmático y comienza a vivir en vilo en el mismo trágico abrazo por el que la razón se vuelve crítica y perpleja. El choque y destrucción de sus certezas respectivas los sume a ambos en la desesperación. Para Unamuno la desesperación es la forma constitutiva de la conciencia. No es una estación de paso en la vida del espíritu, como pensaban Hegel y Kierkegaard, cada uno a su modo, sino el sentimicnto matriz de la libertad. Por decirlo de alguna manera, Unamuno se planta en la desesperación. Pcro lejos de ver en ésta una pasión inútil, ve surgir en ella, como la mariposa de la crisálida, una nueva e intrépida actitud: «Y de este choque, de este abrazo entre la desesperación y el esccpticismo, nace la santa, la dulce, la salvadora incertidumbre ${ }^{44}$. No se trata, pues, de la mera neutralización de dos certezas. La incertidumbre es aquí creadora. La desesperación sentimental y volitiva del corazón, a causa de la crítica racional, se recobra en esperanza a partir del propio carácter escéptico en que se disuelve la razón. Esperanza agónica, ciertamente, contra toda esperanza, y por lo mismo, intrépida y genuina, como lo es también la fe, traspasada por la duda y alcanzada en su vuclo por la crítica racional. Pero también la razón se vuelve agónica en su extrema perplejidad. Claro está que caben otras posibilidades; podría desentenderse del problema como de algo que no le concierne, o declararlo un pseudoproblema, expediente dogmático con que la razón intenta reducir a la nada a cuanto no le puede hincar el diente. Pero todas estas estrategias resultan a la postre falaces. Mientras subsista frente a ella la terca insistencia del corazón, la razón se verá obligada a dar cuenta de sí misma y aguzar su crítica. $Y$ al extremar su criticismo - piensa Unamuno- tendrá que reconocer su condición últimamente escéptica. El abrazo trágico ha transformado a los con-

\footnotetext{
a. Idem, 172.

\$. Idem, 185.

I Idem, 179 .
} 
tendientes: en el fondo del abismo queda una fe cordial que se alimenta de la duda, y en ella contrasta el temple de su esperanza, y una razón que no puede cerrarse dogmáticamente sobre sí misma, porque se encuentra confrontada con una exigencia absoluta a la que no puede integrar ni reducir.

Pero esta incertidumbre, lejos de paralizar, es «salvadora» porque comienza encarando sin disimulo los límites de la propia condición. «La certeza absoluta y la duda absoluta nos están igualmente vedadas - cita Unamuno a Lamennais-. Flotamos en un medio vago entre estos dos extremos, entre el ser y la nada» ${ }^{45}$. Este «entre» es el elemento de la incertidumbre. Una certeza absoluta no se compadece con la condición humana. No coincidiendo con la nada, pero tampoco con el ser, siempre a medias, flotamos en el elemento de la perplejidad. «Hc aquí nuestro estado verdadero - había escrito Pascal-; to que nos hace incapaces de saber con certeza y de ignorar en absoluto ${ }^{46}$. Unamuno reclama para la libertad este espacio intermedio, precisamente aquel en que se movía el eros platónico. Pero lo que es en Pascal una confesión de la miseria humana se trueca en Unamuno en una chance de libertad. «Ambas certezas (esto es, ya sea la de la muerte absoluta o la de la inmortalidad) nos harian igualmente imposible la vida ${ }^{47}$, porque destruirían las condiciones de la lucha por el sentido, que es el ser mismo de la conciencia. Tanto el absoluto pesimismo racional como el absoluto optimismo cordial conducen por distintos derroteros al quietismo, porque nos dejan desarmados. Pero la argumentación podría generalizarse: cualquier certeza absoluta, sea cual fuere su signo, ya sea de la razón o del corazón, haría imposible la vida en libertad. Ésta implica incertidumbre y riesgo, arrojo y aventura, en una palabra, creación. Como ha señalado con acierto M. Merleau-Ponty, ela conciencia metafísica y moral muere en contacto con lo absolutos ${ }^{48}$, porque adormecida a su sombra deja de interrogar y buscar. Inversamente, tampoco en un escepticismo integral sería posible la vida de la conciencia, ya que haría naufragar a radice, aun cuando por opuestas razones, el esfuerzo por el sentido. Entre la certeza absoluta y la duda absoluta sólo queda el espacio intermedio de la incertidumbre creadora.

El fondo del abismo no es, pues, otro que la libertad. La bajada a este fondo constituye la experiencia de la angustia o la congoja. No ya la angustia de la existencia ante su posibilidad, como sostenía Kirkegaard, sino angustia por el propio esfuerzo de ser, siempre crucificado cntre el todo y la nada. ¿Qué cabe hacer entonces? Jugar - había proclamado Nietzsche-, entregarse al juego trágico del ser en que danzan entrelazadas la ilusión y el vacio. Apostar - aconsejaba Pascal-, lo que es otra forma de juego, pero contenida con el rigor del cálculo de lo probable. Luchar es la respuesta de Don Quijote,

\footnotetext{
45 Ibidem.

* «Pensécs $*$, en Oeuvres completes, Gallimard, París, 1854, p. 1109

* Del sentimiento trágico de la vida, OC, VII, 179.

* Sens et non-sens, Nagel, Paris, 1966, p. 167.
} 
esto es, sacar fuerzas de flaqueza para hacer creadora la propia incertidumbre. La libertad trágica se descubre a sí misma angustiosamente, confrontada a un destino de caducidad y muerte, frente al que tiene que hacer prevalecer la eternidad que demanda su obra. No es libre arbitrio ni necesidad racional, sino el esfuerzo titánico por no dimitir en la lucha por dar finalidad humana al universo. En esto consiste precisamente la creación del sentido. Como el eros platónico, que Unamuno mistifica con la piedad cristiana, en la desesperación e incertidumbre sabe encontrar el camino de la creación desesperada.

Llegados a este punto nos asalta una pregunta de gran alcance: icabe tragedia, rigurosa tragedia, en el elemento de la incertidumbre, donde la agonía no rehusa el grito de esperanza? En sentido estricto, creo que no. Donde hay tragedia se da el amor fati o plena asunción del sin-sentido último, y juntamente con ello, la renuncia a toda posibilidad de trascenderlo. La tragedia es la negación de todo finalismo. En este sentido, la tragedia es la negación radical de la dialéctica. La inocencia del devenir es el desafío supremo lanzado por Nietzsche contra toda forma de idealismo, sea kantiano o hegeliano, y su invitación a una voluntad creadora, que sólo se realiza en el arte, donde no cabe ni finalidad ni esperanza. Ciertamente, como se ha indicado, Unamuno se ha opuesto con el mismo empeño tanto al optímismo metafísico de una teología natural, a lo Leibniz, como al pesimismo pasivo que no es más que fatalismo, al modo de Schopenhauer. En la medida en que vuelve a Kant, su posición no tiene ningún tipo de componenda con la metafísica del optimismo ni con la filosofía hegeliana del espíritu. De ahí que su filosofía trágica no tenga nada que ver, como queda dicho, con la dialéctica, donde al cabo la negación es productiva y acaba conduciendo a buen puerto el parto doloroso de la historia. Pero la vuelta a Kant significa también en Unamuno la reintroducción de la finalidad por la vía de la praxis, y con ello de un idealismo de sentido moral que, como demanda y exigencia, no se compadece en última instancia con lo trágico. Si quisiéramos salvar, no obstante, el calificativo de trágico, en que puso tanto énfasis, se trataría de lo trágico cristiano, una figura existencial - la conciencia desgraciada la llamó Hegel- que se extiende epocalmente de Pascal a Kant, de los que Unamuno se sabe tributario. $\mathrm{Y}$ a esta figura, más que tragedia, en el sentido precristiano del têrmino, le conviene el nombre unamuniano de agonía, muy afín, como solía repetir Unamuno, a la agonía de Jesús, el héroe de un cristianismo trágico. Hegel sostenía que la conciencia desgraciada fue superada por el advenimiento de la razón moderna. De la ilusión que comporta este juicio puede dar cuenta el kantismo y todas sus metamorfosis y resurrecciones. Nietzsche, a su vez, creyó que se trataba de una figura perteneciente a la época de un nihilismo incompleto. ¿Hay tambiên en Nietzsche una ilusión ideológica sobre la suerte de la conciencia moral y su sustitución definitiva por el arte? Cuando Unamuno atacaba con tanto ahinco el espíritu del juego sabía, o intuía al menos, a qué gran desafío se enfrentaba. En el juego se mantiene lo trágico sobre la renuncia 
a toda esperanza. Pero la creación ética y poética, al modo como la concibió Unamuno, era en el fondo una apuesta por la esperanza, siquiera sea desesperada.

4.2. El paradigma de la reflexión: Ortega rechazó frontalmente este clima patético, exasperado, por opuesto a la actitud filosófica genuina. En el fondo éste fue el duro reproche que dirigió al existencialismo: su reducción de la filosofía a puro «compromiso», a mero testimonio de creencias, como si el engagement fuese el criterio de la verdad. Pero «la filosofía - replica Ortegano es demostrar con la vida lo que es la verdad, sino estrictamente lo contrario, demostrar la verdad para, gracias a ello, poder vivir auténticamente» ${ }^{49}$. A partir, pues, de su abandono del neokantismo y desde el comienzo de su nueva singladura fenomenológica, la obra de Ortega se endereza a combatir la concepción trágica de la vida. Ya en Meditaciones del Quijote se anuncia claramente este propósito: «Esta misma oposición, tan usada hoy por los que no quieren trabajar, entre razón y vida es ya sospechosa, iComo si la razón no fuera una función vital y espontánea del mismo linaje que el ver o el palpar!» ${ }^{50}$. Sin duda éste es el texto originario del raciovitalismo orteguiano en réplica directa al tragicismo de Unamuno. Con vistas a esta superación, tiene que intentar una vigorosa rectificación de los términos en litigio. En el paradigma trágico se mantiene la antinomia, en sentido pre-dialéctico, entre mecanicismo y teleología, ser y deber-ser, en virtud de un concepto estrecho y positivista de razón junto a una idea peraltada y espiritualista de la vida. Era menester, pues, proceder a un nuevo replanteamiento del problema. De un lado, ensancha el concepto de razón hasta hacerla coincidir con el logos en su versión originaria, la capacidad de asistir la vida y orientarla según principios específicos de las diversas esferas de actuación. Del otro, reduce la vida del espíritu a cultura genérica (ciencia, moral, derecho, arte; ninguna mención a la religión, que era el campo unamuniano de batalla con su economía a lo trascendente), que requiere la vida individual para constituir y definir su proyecto vital. Vida, pues, en un sentido biográfico como tarea de autorrealización, y razón en sentido vital, como subraya Ortega, en cuanto función al servicio de la vida.

Quedan así defínidos los dos polos que no son exclusivos sino inclusivos. La vida humana es siempre, lo sepa o no, incoactivamente racional, pues despliega una intencionalidad práxica o ejecutiva, y la razón es implícitamente vital, pues sanciona aquella ilustración inmanente que opera siempre en el seno de la vida. Claro está que hay diferencias que impiden su confusión. La vida es siempre vida inmediata, elemental y espontánea de un yo; su actividad ejecutiva o experimentadora del mundo pone en juego una racionalidad incoativa que aún no ha sido decantada en principios. Esto hace de ella un problema, esto es, una permanente cuestión de orientación y justificación. La vida ha de saber a qué atenerse, cómo comportarse en vistas de su circunstancia, con

La idea de principio en Leibniz, OC, VII, 316.
Meditaciones del Quijote, OC, I, 353. 
arreglo a qué criterios decidir sus opciones y definir sus metas. A su vez, la razón, o la cultura, asiste a la vida en la medida en que le proporciona claridad y seguridad. El hombre piensa para estar seguro en la medida que logra estar en lo seguro acerca de las cosas de su vida. Pero lo seguro de éstas es su ser o su sentido en la acepción no moral idealista, sino fenomenológica del término. Por eso sólo logra estar seguro quien utiliza el órgano, el concepto, esto es, quien vive de la razón, que es, por tanto, rigurosamente hablando, razón vital. «Para dominar el indócil torrente de la vida medita el sabio, tiembla el poeta y levanta la barbacana de su voluntad el héoe político. iBueno fuera que el producto de todas estas solicitudes no llevara más que a duplicar el problema del universo! No, no; el hombre tiene una misión de claridad sobre la tierra» ${ }^{51}$. Con ello alude Ortega a la ilustración (Aufklärung), que surge de la vida, a instancias de ella, movida por sus necesidades y motivaciones. Si la vida inmediata es problema, es decir, contingencia y suerte azarosa, la razón o la cultura representa, en cambio, el sistema de las respuestas bien probadas y contrastadas, el tesoro de los principios. Pero éstos sólo han podido surgir del ensayo permanente que es la vida misma. La primacia es siempre de la vida, como consagra un temprano texto de Meditaciones del Quijote: «la vida es el texto eterno, la retama ardiendo al borde del camino donde Dios da sus voces. La cultura -arte o ciencia o política - es aquel modo de vida en que, refractándose ésta dentro de sí misma, adquiere pulimento y ordenación» ${ }^{52}$. En otros téminos, la razón o cultura es vida en reflexión, refractándose en sí, y la vida resulta ser entonces posesión plena de sí misma, vida en forma. «Claridad no es la vida, pero es la plenitud de la vida» ${ }^{53}$.

Esta primacía de la vida es elevada explícitamente a principio de los principios en El tema de nuestro tiempo, donde Ortega critica, precisamente desde la instancia de la vida, la hipertrofia de la cultura como un mundo en sí y su hipóstasis metafísica sobre la vida. El nuevo lema es ahora, en contra de la beatería culturalista, «la cultura para la vida», que es en verdad to único que merece la dignidad de un principio. Esto explica que Ortega insista más ahora en el factor de la creatividad de la vida y su sentido ascendente sobre las formas ya dadas de cultura. «La vida organizada, la vida como uso de órganos, es vida secundaria y derivada, es vida de segunda clase. La vida organizante es la vida primaria y radical» ${ }^{54}$. Lo que está ahora en juego no es la necesidad de la reflexión para superar la inmediatez de la vida, sino, inversamente, la necesidad de la creación para que los productos vitales no degeneren en otra forma de inmediatez cultural, a expensas de la vida. Pero Ortega no defiende en esta obra una filosofía antirreflexiva, que lo acercaría a los irracionalismos al uso, sino una filosofía crítica de la cultura (o de la razón),

\footnotetext{
si liem, I, 357.

5? Ibidem.

siem, 1, 358 .

s4 El Quijote en la escuela», OC, II, 280.
} 
desde aquella instancia que es, a la vez, inmanente y trascendente a la cultura, la natura naturans originaria, la vida en su espontaneidad creadora. De ahí que a la ironía socrática con que la cultura burla la espontaneidad de la vida contraponga ahora Ortega la otra ironía de don Juan con que la vida, llegado el caso, se burla de la majestad de la cultura. Los dos polos subsisten sin confusión, y no en vano acaba la obra apelando a una reconciliación entre vitalismo y culturalismo ${ }^{55}$. Pero no cabe tal reconciliación al margen de la reflexión, en que se produce la unidad funcional de ambos.

Podría decirse que la reflexión representa la alternativa orteguiana al paradigma unamuniano. No hay, pues, antinomia trágica entre vida y razón, sino oposición funcional inmanente. Subsisten dos polos que no se pueden recubrir ni reabsorber el uno en el otro - el de la conciencia ejecutiva de la participación en ser y el de la autoconciencia objetivadora- La reflexión constituye precisamente el circuito interno que los enlaza. Fuera de estc circuito, los dos polos, vida y razón, caen en una relación de indiferencia cuando no de abierto antagonismo. Pero bien entendido que el único principio, la natura naturas, es la vida, en su intencionalidad experimentadora. Ésta era la corrección orteguiana al idealismo husserliano. Pero la vida, aparte de su compromiso ejecutivo en el mundo, puede volverse sobre sí misma. Son dos actitudes contrarias/complementarias. En tal caso, se trata de un darse cuenta activo («un ver interpretando o un interpretar viendo", como define Ortega la labor del concepto) que, por asi decirlo, hace la cuenta de lo ejecutado y lo capta en su sentido u objetividad. Esta toma de distancia es una vuelta o retracción de la inmediatez, una suerte de ascetismo por el que la vida se suspende en su ejecutividad para verse en su objetividad y llegar a ser traslúcida para sí misma. La reflexión es un modo de des-vivirse o de tomar distancia sobre lo vivido, la justa para ver mejor. Distanciamiento, pues, de lo inmediato y suspensión de la espontaneidad a fin de poder ver las cosas de la circunstancia en su sentido inmanente y complacerse en ellas con el amor intelectual, que es amor de contemplación ${ }^{56}$. De este modo se eleva a autoconciencia temática explícita la conciencia ejecutiva y difusa que hay en el seno de la vida. Esta transformación interior de la vida es la obra especifica de la reflexión. Así asegura Ortega desde el umbral mismo de su filosofía que «el acto específicamente cultural es cl creador, aquel en que extraemos el logos de algo que todavía era insignificante (i-lógico)» ${ }^{57}$. Pero conviene no olvidar que se trata de una creación en segunda potencia, pues antes le ha precedido el acto ejecutivo, en que estaba la intencionalidad insurgente de la vida. Mas para evitar que este logos cultural se sustantive y autonomice cono algo en sí es preciso devolverlo a la circunstancia a la que pertenece. Tras la retracción o distanciamiento, necesarias para objetivar el sentido, ha de sobrevenir, como su movimiento complementario, la conversión

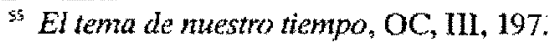

Meditacioney del Quijote, OC, $1,312-3$.

"ldem, I, 321. 
o vuelta táctica a lo inmediato, insertando el sentido en la carne del mundo de que ha surgido. Se cicrra así el circuito entre vida y razón. Hay, pues, una tensión inmanente a la vida entre la ejecutividad de su compromiso en el mundo y la reflexividad que capta el sentido del mismo. $\mathrm{O}$ dicho en otros términos, entre el natural dejarse vivir en cada acto y el metódico des-vivirse por recuperar objetivamente la intencionalidad puesta en obra; en fin, entre la vida ocupada o preocupada y la vida alerta.

Las metáforas de la reflexión muestran precisamente el carácter productivo de esta tensión; todas tienen que ver con el cristal en que la turbia intencionalidad de la vida cjecutiva se vuelve traslúcida. «Acontece lo que con el cristal, medio transparente a través del cual vemos los demás objetos», pcro él mismo no se deja fácilmente ver. «Para llegar a percibirlo es preciso que nos desentendamos de todo aquello a que el vidrio nos lleva y retraigamos sobre ćl la mirada, sobre su irónica sustancia, que parece anularsc a sí misma y dejar transir por las cosas de más allás ${ }^{58}$. Este cristal es el ojo de la reflexión. «Lo único que afirmo es que sobre la vida espontánca debe abrir, de cuando en cuando, su clara pupila la teoría» ${ }^{59}$. Ya se trate del espejo bruñido en quc al refractarse los temas de nuestro interés arrojan innumerables reverberaciones, o del prisma que interpuesto entre la vida y la autoconcicncia hace que aquélla se proyecte en un arcoiris multicolor, la reflexión es siempre un acto de autoposesión esciente de la propia vida. Reflexión, pues, de la vida, pcro no para inhibirla o mermarla, sino precisamente para potenciarla en su poder inmanente. Ahora bien, para Ortega este circuito es el clcmento de la libertad. A diferencia de Unamuno, que situaba la libertad en cl fondo del abismo, que es la incertidumbre creadora, Ortega la resitúa en el movimiento de ida y vuelta de la reflexión, donde brota toda posible certidumbre. La libertad es el tránsito de la vida espontánea a la vida reflexiva, o dicho a la inversa, el modo en que la vida reflexiva se incorpora a la vida creadora. Ensayando el quiasmo, se diría que la libertad es la vida confirmada por el poder de la razón o la razón animada, vivificada, por el impulso a más vida. Libertad no sólo como dominio de las cosas, salvadas en su sentido, sino como autonomía y autarquía soberanas. Libertad como forma de ser-se, de asistirse e incluso de sobrevivirse o trascenderse en nuevas formas y experiencias. Como una réplica directa a los alegatos unamunianos de que la razón inhibe y paraliza la vida, negándole su pretensión de sobrevida, suena este exultante texto orteguiano: «Quién sabe, no obstante, si bajo este aparente ascetismo y distancimiento de la vida, que es el estricto pensar, no se oculta una máxima forma de vitalidad, su lujo supremo! iQuién sabe si pensar en la vida no es añadir al ingenuo vivirla, un magnífico afán de sobrevivirla!» ${ }^{60}$. Esta vida confirmada, en posesión esciente de sí misma y disposición creadora de sus potencialidades,

El tema de nuestro tiempo, OC, III, 188.

\% Verdad y perspectiva, OC, II, 18.

(*) ¿Qué es filosofia?, OC, VII, 349. 
es la vida en plena forma. Pero en esto consiste precisamente el régimen de salud en que cifraba Ortega su ideal de clasicidad. La salud se da en el intercambio y equilibrio fecundo entre los dos polos -el de la vida y el de la razón-, de modo que cada uno, haciéndose valer por sí mismo, redunde positivamente en la acción del otro. En última instancia, el régimen de salud vital depende de que no se obture el circuito de la reflexión entre vida espontánea e inmediata y vida autoconsciente, entre vida creadora y vida contempladora, pucs sólo entonces la vida puede llegar a ser, a la vez, como pretendía Ortega, un valiente experimento y un armonioso espectáculo.

Podría objetarse tal vez que este modelo de la reflcxión no parece hacer justicia a la obra de Ortega, pues se identifica por lo general a la reflexión con la filosofía de la conciencia, y la de Ortega quiso ser fundamentamente una filosofía de la vida. No puede desconocerse, por otra parte, que cl mismo Ortega había dirigido severas críticas al método reflexivo husserliano. «Para que el idealismo tuviera sentido -escribe- fuera preciso que un acto de conciencia fuera capaz de reflexión sobre sí mismo y no sólo sobre otro acto de conciencia»" ". Pero nótese que lo que critica Ortega no es tanto el movimiento retrospectivo de la reflexión cuanto su hipóstasis trascendental en un yo puro o autoconciencia, que intuye el acto que realiza el yo ejecutivo, suplantándolo así a éste en el orden de la fundamentación. Para Ortega, en cambio, la reflexión es secundaria porque pre-supone a la conciencia ejecutiva. «Prosuponer» signica aquí no sólo tenerla por delante, como su antecedente, sino tenerla por debajo, como su fundamento. «La supuesta conciencia refleja, que pretende descubrir la verdadera y absoluta realidad como conciencia pura y vivencia, es, por el contrario, menos fundamental que la conciencia primaria: primero, porque implica ya a ésta como su propio objeto, y segundo porque, en definitiva, ella es también ingenua e irreflexiva conciencia primaria» ${ }^{62}$. En definitiva, la posición absoluta de la conciencia natural ejecutiva es para Ortega la originaria, pues es la única que encierra una pretensión de realidad y envuelve un compromiso ontológico. De ahí su oposición a la reducción trascendental husserliana como una distorsión de la conciencia ejecutiva en su relación primordial con la realidad. Lo que se niega, en consecuencia, es la tesis idealista de la autoconciencia como fundamento constituyente, y frente a ella, Ortega erige a la vida, como queda dicho, en cuanto natura naturans. Pero esto no significa renunciar a la reflexividad inmanente al darse cuenta específico de toda conciencia, también de la natural, ni a la necesidad en que éstá se encuentra de trascenderse o alargarse en vida explicita autoconsciente, que «da cuenta» en tanto que interpreta el sentido de su acto (razón vital), o bien «hace la cuenta» (razón histórica) de sus diversas experiencias en su conexión dialéctica inmanente. Hasta tal punto es necesario este trascendimiento que el yo personal

it «Prólogo para alemanes», OC, VIII, 50.

6. Ibiden. 
no es para Ortega más que la integración armónica del yo ejecutivo y el yo reflexivo, en un equilibrio dinámico entre experimento creativo y contemplación.

4.3. El paradigma especulativo: Decía antes que el empeño de Zubiri no era otro que restaurar la metafísica, como resolución de la crisis de la razón, radicando así a la inteligencia en la realidad. Ahora bien, en su propósito de superar el idealismo de la modernidad Zubiri va más lejos, esto es, más radicalmente que Ortega al centro de la cuestión. No basta con situarse en el nivel de la conciencia ejecutiva como un habérselas con las cosas si no se da una génesis o posibilitación del «habérselas con» en el previo o apriórico «estar-en-realidad». Ortega se ha limitado a suplantar el cogito reflexivo por un cogito viviente, yendo por dcbajo o por detrás de la conciencia trascendental o pura hacia el fenómeno del ser-en-el-mundo. Con razón ha podido llamar a su filosofía un scartesianismo de la vida», $y$, consecuentemente, entender la vida como realidad radical, tal como como lo era el cogito en la tradición moderna. Su metafísica de la vida o de la razón vital no deja de ser una forma de humanismo, centrado en la subjetividad real. Pero en esto veía Zubiri un ricsgo de antropologismo, el intento de elucidar el scr y la verdad en función del hombre. $\mathrm{Y}$ de ahí su búsqueda de un acto originario en que se diera (actualizara), conjuntamente con la conciencia del acto, la impresión de realidad. De la inteligencia sentiente zubiriana, aun siendo un acto originario, en modo alguno puede decirse que sea la realidad radical, sino radicada o arraigada, pues el sentirse real de la inteligencia es inseparable de su sentir la realidad como algo que ella no pone ni construye, sino que se le im-pone en impresión, afectándola y actualizándola en su propio acto de inteligir. A un planteamiento tan radicalmente ontológico no le conviene el nombre de filosofía de la reflexión, ya se entienda ésta en sentido trascendental husserliano o en el retrospectivo orteguiano.Todos los términos tienen que ser reacuñados en forma nueva. No hay un sujeto previo a las vivencias y depositario de ellas, sino que ser inversamente la subjetividad, esto es, la interioridad del propio acto, supone el ser cabe sí, presente a sí, no por modo reflexivo, sino vivencial o actual, en que está la inteligencia cuando se actualiza o hace presente en ella la realidad. No cabe vuelta reflexiva sobre sí si el sujeto no está ya de antemano cabe sí. «No se entra en sí mismo - precisa Zubiri- sino sintiéndose a sí mismo» ${ }^{63}$. $\mathrm{Y}$ tal sentir-se es solidario y conjunto con el sentir realidad. «La intelección sentiente no se da en la subjetividad, sino que, por el contrario - precisa Zubiri-, la intelección sentiente como mera actualización de lo real es la constitución misma de la subjetividad, es la apertura al ámbito del mi» ${ }^{64}$. Conjuntamente acontece el trascender desde y hacia la realidad y el retroscender a la interioridad del propio acto, el despliegue progresivo del ámbito trascendental de lo real desde la impresión de la realidad y el repliegue intensivo

${ }^{3}$ Intchigencia sentiente, op. cit., 109.

- Ídem, 165. 
reflexivo en el ser cabe sí. «Y esta intelección de mi propia intimidad en su dentro es una intelección de mí a través del estar: es justo la reflexión» ${ }^{6:}$. A una reflexión de esta índole me atrevería a calificarla de interna, pues no es un acto que recae sobre otro acto, sino la cxperiencia gradual interiorizadora del propio acto, gestada a la par que se expone en y para la inteligencia el contenido sustancial del mundo.

Tal reflexión interna es propiamente lo especulativo. Conviene despejar el nombre de las sospechas que ha vertido sobre él una filosofia empiricista. Se suele tomar la especulación como un pensamiento que se mueve en el vacío, o bien que trafica fraudulentamente con las ideas, generando una plusvalía intelectual, puramente espectral. Pero asombra saber que lo especulativo primigeniamente designó un pensamiento que se sabía deudor y tributario de la realidad, hasta tal punto de no ser más que su exponente. I a metáfora del espejo (speculum) guardaba esta connotación de fidelidad a la cosa que en él se reproduce. No se atendía a la ley de reflexión o refracción por la que él determina sus imágenes, sino a la remisión o reflexión con que éstas reproducen lo real en cuanto tal. El secreto del espejo es que no se puede sustantivar la imagen como algo para sí, sino que remite al original como la cosa cn sí misma. En este sentido, lo especulativo es lo esencialmente antidogmático ${ }^{66}$, pues obliga a reconocer en el espejo no su imagen por (en lugar de) la cosa, sino lo debido a la cosa. Como cnseñó Tomás de Aquino, «ver, pues, algo mediante el espejo es ver la causa por el efecto, en que reluce la semejanza de ella. Por donde la especulación puede ser reducida a la meditacións ${ }^{67}$, esto es, a la atenta ponderación del vínculo ontológico entre la imagen creada y su original. Hegel, desde supuestos ya secularizados, no enseñó otra cosa cuando entendía lo especulativo como «un saber del contenido en la misma medida en que ese contenido es concepto y esencia* ${ }^{68}$, es decir, no un saber construido mediante conceptos subjetivos o esquemas previos, sino aquel otro que, por el contrario, expresa el movimiento conceptual que acontece en la cosa misma, en tanto que ésta se muestra o expone y recoge en su esencialidad, hasta el punto de que cl concepto es ontológico, pues no es más que la cosa misma en la unidad reflexiva de sus determinaciones. A esto llamaba Hegel la reflexión interna, que se produce en y mediante la cosa misma, y no por obra de un sujeto que actuara sobre ella desde fuera, sometiéndola y configurándola según su propia legalidad inmanente. La reflexion no es ya más la refracción de la cosa en un medio extraño, sino la exposición en la inteligencia del orden de la realidad en cuanto tal.

La metáfora del espejo, en su sentido propio, conviene bien, a mi juicio, a la teoría zubiriana de la inteligencia sentiente. «¿De dónde arranca, en qué

Idem, 108 .

*6r. Hans-Georg Gadamer, Verdad y Método, Sígueme, Salamanca, 1993, p. 558.

" Summa Theologiae, II-Ilae, qu. 180, art. 3, ad secundum.

${ }^{68}$ Phaenomenologie des Geistes, Meiner, Hamburg, 1952, p. 47, trad. esp. de W. Roces, FCE, México, 1966, Prólogo, p. 38. 
consiste, en última instancia -se pregunta Zubiri-, la última razón de la existencia humana como luz de las $\cos a s ? »{ }^{69}$. Y en su respuesta apunta a un desplazamiento de la cuestión del ser a lo que está «más allá dcl scr», esto es, más radicalmente en dirección del fundamento, que es la realidad. De donde resulta que la luz del ser, en que existe el hombre, es la reverberación del foco luminoso que hay en la cosa misma. Se diría que la inteligencia ve la cosa en su propia luz, a su resol, al igual que la palabra corresponde a la voz de la realidad. La inteligencia no es más que el portavoz, según Zubiri, de lo que la cosa dice de sí y pro-clama por sí misma. Esto no significa que el espejo se instale de una vez por todas en una visión traslúcida. En cuanto espejo viviente, realiza más bien su vocación de transparencia en una progresiva depuración de su azogue, ateniéndose a la disciplina de la cosa misma, esto es, al modo de su ex-posición en el ámbito del mundo y de su reflexión progresiva en la unidad de todas sus determinaciones. La inteligencia sentiente, en tanto que dinámicamente instada cn y por la formalidad abierta de la realidad, no es dogmática sino crítica, con tal de que no se entienda por ello una crítica en sentido cpistemológico de la facultad de inteligir, de sus límites y posibilidades. Se trata, por el contrario, de la crítica inmanente a la experiencia misma de la cosa que se actualiza, en cl contcxto abierto del mundo, conforme a los modos de su exposición. De ahí la necesidad de que la inteligencia sentiente se complete en otras modalizaciones de intelección para explorar el horizonte de la realidad, ya sea como logos o como ratio, esto es, como pensar discursivo que pretende «decir lo que la cosa real es en realidad» ${ }^{70}$, en la intrincada red de relaciones con otras cosas, que constituyen el contexto del mundo, y como pensar explicativo respectivamente, que pretende progresivamente dar razón y fundamentar.

Pero lo que más importa al caso, en comparación con los paradigmas trágico y reflexivo, respectivamente, de Unamuno y Ortega, es la nueva idea de libertad que surge de este planteamiento, y a la que llamaría libertad trascendental por recubrirse con el horizonte abierto de lo real en cuanto tal, es decir, del mundo como sistema de todo lo real. Al arraigar en el poder de la realidad el hombre encuentra de nuevo el sentido de su propio ser. Éste no es otro que la libertad como disposición para estar y mantenerse en lo abierto, es decir, en la apertura a la realidad. En virtud de ella, la libertad del hombre significa la liberación de la fuerza impulsiva y tendencial de la vida animal y la franquía del nuevo horizonte de la realidad en que puede hacerse cargo de la situación. Es la libertad «de» y la libertad «para», como suele decir Zubiri; es decir, la indeterminación en que queda la vida en la suspensión de sus tendencias y la consecuente necesidad de buscar una salida en el nuevo nivel de la autodeterminación de la propia figura de realidad. «La liberación consiste en lanzar al hombre desde sí mismo sobre sí mismo. Con lo cual

${ }^{69}$ Naturaleza, Historia, Dios, op. cit, 235.

7n Ineligencia y logos, Alianza Editorial, Madrid, 1982, p. 51. 
cl hombre no anula las tendencias, sino que detemina cuál de ellas le va a llevar a su acción, cuál de ellas va cobrar vigencia» " ${ }^{7}$. Mas esta libertad «de» y «para» se funda en última instancia en la libertad «en», es decir, en el estar en realidad y mantenerse en lo abierto del mundo, y, por tanto, de sí mismo. «Es justamente libertad en —precisa Zubiri-... El hombre es libre en la realidad en cuanto tal. Por ser justamente de aquella condición en virtud de la cual yo soy mío, me pertenezco a mí mismo y no a otra realidad. La libertad en este sentido es o puede ser idéntica a la persona. No lo es en los dos primeros, pero sí lo es radical y eminentemente en este tercero. Es ser libre» ${ }^{72}$. Se es libre, radical y primordialmente, porque se está en realidad. Este kestar en» significa no sólo que el hombre está abierto a las cosas, sino a su propia realidad, y por eso puede hacerse cargo de sí mismo. No solamente «es» real sino que «se es» real, porque puede comportarse «respecto de su propio carácter de realidads ${ }^{73}$. La sustantividad abierta es, por eso, por modo constitutivo, persona. Para Zubiri ser persona consiste en ser en propiedad de sí. «La suidad es la raiz y el carácter formal de la personeidad» ${ }^{74}$. No ya ser «de suyo», como todo lo real, sino ser-suyo, poder entrar en posesión de sí mismo, pertenecer-se en el orden de la realidad, porque se está en la obra de sí. No se trata, sin embargo, como bien advierte, de ningûn carácter reflexivo ni moral, de ninguna cualificación en el ejercicio de la propia realidad, sino de una estructura constitutiva. Se es persona, y se es persona en virtud de la inteligencia como raíz de la apertura: "La inteligencia, en efecto, es la estructura radical que el hombre posee, en virtud de la cual se enfrenta $\longrightarrow$ al menos puede enfrentarse en principio - con el resto de la realidad y hasta con su propia realidad $\%{ }^{75}$. Claro está que este estar abierto a la realidad no puede tomarse como una indigencia o menesterosidad de ser, como se ha insistido patéticamente desde el existencialismo. Al hombre no le falta la realidad, sino que precisamente le asiste. Y ni siquiera puede decirse que le falte la suya, pues se tiene como suyo, con anterioridad al cjercicio de la reflexión, en la totalidad de sus actos. Incluso su tener que hacerse, darse una figura de vida - su personalidad--, no es algo defectivo sino perfectivo, en tanto que pone en su mano, en su propia libertad, el sentido y el valor de su vida. En cuanto abierto a la realidad, el hombre no es un indigente sino, en cierto modo, un ab-soluto. Su libertad es «un acto de cuasi creación» ${ }^{76}$, porque le conficre el poder de determinación del propio ser. Ab-soluto en el sentido de suelto de y enfrentado al todo de lo real, en tanto que abierto trascendentalmente al horizonte de la realidad. Pero a la vez, como bien advicrte Zubiri, un ab-soluto relativo,

\footnotetext{
${ }^{7}$ Sobre el hombre, Alianza Editorial, Madrid, 1986, p. 597.

${ }^{72}$ El hombre y Dios, Alianza Editorial, Madrid, 1988, p. 330.

Idem, 48 .

7 Idem, 49.

Sobre el hombre, op cit, $117-8$.

70 flem, 604
} 
no sólo por ser cobrado, esto es, ganado, siendo, sino por estar referido constitutivamente a la realidad, que él no puede poner ${ }^{77}$. En cuanto se relaciona con la realidad simpliciter, y, por tanto, con la suya propia, trasciende toda forma concreta y particular de realidad. De ahí que cste absoluto/relativo se encuentre en un movimiento de trascendencia de las cosas, pero en la realidad. En cuanto ab-soluto, su libertad significa trascendencia de cualquier cosa concreta «hacia» la realidad, pero, a la vez, en cuanto relativo, estancia en la realidad como en el horizonte trascendental de inmoración. La libertad es, en definitiva, quedarse en esta experiencia originaria y arraigar en ella. En verdad, el «animal de realidades» está en sobre-determinación en virtud del excessus o apertura de la inteligencia al orden trascendental de la realidad. De ahí que su auto-determinación no sea tanto la salida de la in-determinación cuanto la contracción, aquí y ahora, en un bien particular, de su sobredeterminación originaria ${ }^{78}$. Por eso, como clama Zubiri, el único remedio para la profunda crisis de desarraigo que sufre el hombre de hoy no es la proclama retórica humanista, sino volver a recuperar el sentido de la realidad.

\section{Filosofias de la praxis}

Anunciaba al comienzo que la afinidad entre estos tres modelos de filosofar estaba en ser filosofías de la vida, que alumbran, cada una a su modo, una nueva praxis en su respuesta a la crisis de Occidente.

5.1. En Unamuno se trata de una filosofía moral, a la que vengo llamando idealismo ético por su inspiración kantiana/fichteana, y que encarna en la figura de Don Quijote, convertido en héroe trágico, empeñado en una batalla contra el mundo por realizar su ideal trascendente. Un Don Quijote exultante y utopista en su primera aparición en Vida de Don Quijote y Sancho, bien distinto del melancólico y sombrío de obras posteriores, según internaliza su campo de batalla y toma conciencia de la profundidad de su agonismo. La ficción literaria cervantina se convierte en la lectura unamuniana en el medio de una revelación trascendente: Don Quijote es un arquetipo moral o idea viva, y, por tanto, según la óptica de Unamuno, un ser de bulto y sustancia porque realiza el acto de autoafirmación de sí como voluntad de ser y de sobrevivirse. En Don Quijote vale eminentemente que «existir es obrar» - tesis básica del idealismo de la libertad-, pues "es el fin de la vida hacerse un alma» ${ }^{79}$. Y, en efecto, Alonso Quijano se hace un alma al elegirse en su vocación quijotesca, pues en el personaje de Don Quijote está la finalidad trascendente que da sentido a su vida. La existencia heroica se esfuerza por fraguar en el tiempo su símbolo o arquetipo, su yo ideal y eterno, y en esta medida, se eterniza a sí misma.

\footnotetext{
"El hombre y Dios, op. cil. 79.

* Sobre el hombre, op cit, 603-4.

$7 \mathrm{OC}, \mathrm{VI}, 341$.
} 
De ahí que el primer acto del héroe consista en acertarse en su símbolo, es decir, en la clccción originaria de sí mismo en lo que ha de ser, porque lo quiere ser incondicionalmente, y en ponerse un nombre, como «convenía a su renovación interior» ${ }^{80}$. De este modo, «sometióse a su propia idea, al Don Quijote eterno, a la memoria que de él quedase» ${ }^{81}$. Para Alonso Quijano, Don Quijote es su verdadera alma, donde está el pondus o el centro de gravedad de su existencia. "Yo sé quién soy" - exclama Don Quijote a la vuelta de su primer infortunio-, y sólo el héroe lo sabe, pues está a la raíz de su ser y se conoce desde el querer originario con que inventa o halla su figura de existencia. «Don Quijote discurría con la voluntad -comenta Unamuno-, y al decir yo sé quién soy, no dijo sino yo sé quién quiero ser. $\mathrm{Y}$ es el quid. de la vida humana toda: saber el hombre lo que quiere ser. El ser que eres no es más que un ser caduco y perecedero que come de la tierra y al que la tierra se lo comerá un día; el que quieres ser es tu idea en Dios, Conciencia del Universo, es la divina idea de que eres manifestación en el tiempo y en el espacio» ${ }^{82}$. La vocación tiene aquí un sentido ético/religioso como el modo de sentirse interpelado por un ideal moral excelso, en el que encuentra el yo su ideal de perfección, lo que llama Unamuno enfáticamente la idea absoluta de mi yo o de mi yo en lo absoluto. El descubrimiento de la vocación en un acto de fe en que se revela, de una vez por todas, el sentido integral de la vida.

El segundo acto heroico es trascenderse en una obra que sea el trasunto del alma, «y hay alma donde hay finalidad» (VII, 116 y 245), esto es, donde la conciencia proyecta y realiza fines que puedan generar un universo moral. Ahora bien, en cuanto este mundo nouménico sustancial, según lo llama Unamuno, entra en colisión con el otro fenoménico y apariencial, su obra es una hazaña heroica. Se trata de una creación voluntarista de valor, ardua y a la desesperada, porque no cuenta con la posibilidad de medirse racionalmente con lo fáctico/positivo. En este sentido, Don Quijote representa lo que llamó Hegel el caballero de la virtud, que fiado en la ley de su corazón, verdadero asiento para sí de lo universal, se enfrenta resueltamente con el curso del mundo. Con la hazaña virtuosa entra, pues, en acción el espíritu de la utopía contra la inerte y terca facticidad del mundo, oponiéndole su pura fe en lo universal, que le dicta su corazón. Al héroe no le importa su derrota. Se diría más bien que cuenta de antemano con ella, pues ha elegido sucumbir antes que apartarse de su ideal. Quizá también, como sugirió Hegel, porque cuenta con la certeza moral del triunfo definitivo de la idea. Sea de ello lo que fuere, el héroe vive en guerra permanente con el mundo con tal de realizar su símbolo. $\mathrm{Y}$ como no hay yo sin mundo, se esfuerza por instituirse como centro del universo y hacer un mundo conforme a su idea. El mundo ha de ser, por

* Vida de Don Quijote y Sancho, OC, 1II, 70.

"Ilem, 69.

s2 Idem, 82. 
tanto, su creación, un poema libre de su fe y de su esfuerzo. Pero no se le oculta que la facticidad es refractaria al orden de la idealidad, y que entre ambos mundos, el nouménico y el fenoménico, no cabe transacción sino guerra permanente. A su vez, esta tensión agónica se traduce subjetivamente en la discordia intestina entre la razón que muestra el mundo tal como es de hecho y la fe que lo quiere según el ideal de las aspiraciones morales. Don Quijote también supo de estas intimas torturas, porque no era un visionario y no se le ocultaban los engaños y argucias con que el mundo se burlaba de su esfuerzo.

Pero, sobre todo, Don Quijote simboliza, a los ojos de Unamuno, la voluntad de no morir; no sólo el amor a la gloria y la fama, sino el ansia de sobrevida. De ahí que tuviera que entrar en él en colisión el humanismo secular y el trascendentalismo religioso. Colisión agónica, pero por lo mismo productiva de inquietud y búsqueda frente a la beata y satisfecha adoración de la Kultura, como escribe Unamuno irónicamente enfatizando cl nombre a la alemana, es decir, el nuevo orden trascendental y secular del valor. Para Unamuno el «mal del siglo», que él mismo había experimentado en su crisis espiritual, era tan sólo el episodio final de una larga crisis consustancial a la conciencia moderna entre la cultura cientifico/positiva y la fe religiosa. La Kultura, representada según él por la Helena del Doctor Fausto, de Marlowe, símbolo de los ideales sccularizadores - el progreso, el bienestar, la felicidad-con sus besos le ha sorbido a Fausto la voluntad, y éste, seducido por las promesas de Helena, se ha dejado robar el alma, esto es, el empeño religioso por la preservación eterna de la identidad personal. Su aspiración trascendente ha quedado cegada por el cebo de los nuevos ideales humanistas. Pero perdida la fe moral en el porvenir de la conciencia, es decir, en la inmortalidad, ya no es posible, piensa Unamuno, dar finalidad humana al universo. Pero Don Quijute no se deja como Fausto robar el alma con tal de ser fiel a Dulcinea, que trae una promesa de inmortalidad. El alma fáustica quijotesca, cristianizada en el cmpcño de sobrevida, no puede dejarse seducir por los halagos de la cultura. Su señora es Dulcinea, que representa la gloria, y junto con ella, el arrebato de lo eterno. Según la óptica unamuniana, cl humanismo se desliza insensiblemente de la ética a la estética, convirtiéndose así en mera postura, cn la medida en que no puede ofrecer un fundamento consistente del orden moral. Lo peculiar del mero humanismo es vivir referido al saeculum, al mundo secular como el horizonte propio y exclusivo de la existencia. En la tragedia, en cambio, el hombre ha sido arrebatado del curso ordinario del devenir y enfrentado a una exigencia absoluta. Se diría que en este instante Don Quijote encuentra el alma que había perdido el doctor Fausto. De ahí que entienda Unamuno el quijotismo como una respuesta a la crisis finisecular de la cultura, avivando en ella el sentido religioso trascendente.

En este tránsito de lo ético a lo religioso, al modo quijotesco, creía reconocer Unamuno, por lo demás, un rasgo de la idiosincrasia española: «Pero hay algo que nos ha preocupado siempre tanto o más que pasar el rato - fórmula 
que marca una posición estética- y que es ganar la eternidad, fórmula de la posición religiosa» ".3. No significaba esto, en modo alguno, una vuelta al rancio y beligerante catolicismo castizo. Don Quijote no era, en este sentido, un héroe casticista. Representaba a sus ojos un cristianismo interior y evangélico, de gran aliento civil y de signo opuesto al dogmatismo y fanatismo dominantes. De este modo y simultáneamente, como en un doble movimiento complementario, la conversión religiosa del humanismo, abriéndolo, aun agónicamente, a la preocupación religiosa trascendente, exigía también, a su entender, una conversión humanista y ética del interés religioso, proyectándolo en la vida civil. «Hay que civilizar el Cristianismo» - será la consigna de Unamuno, empenado desde comienzos de siglo en una revolución religiosa interior- « $\mathrm{Y}$ por civilizar entended hacerlo civil para que deje de ser eclesiástico; infundirlo en la vida civil, en la civilidad, desempeñándolo de la Iglesia» ${ }^{84}$. Éste es el germen de su fórmula posterior «desamortización del Evangelio» ${ }^{85}$, volviéndolo plenamente secular y civil, esto es, una fuerza productiva de libertad y solidaridad, de exigencia interior y de convivencia. No es extraño que el quijotismo se convierta a sus ojos en una nueva forma de religión, la religión nacional, y Don Quijote en el aCristo español, en que se cifra y encierra el alma inmortal de este mi pueblo»"

5.2. Se comprende que para plantar batalla a este idealismo moral de signo quijotesco se vea obligado Ortega a hacer otra lectura práctica, ético/política de El Qujote, no en términos del espíritu del personaje, sino del libro, esto es, «el estilo cervantino, la manera cervantina de acercarse a las cosas». Con este decisivo vuelco hermenéutico cambia radicalmente el sentido de la cuestión. Ya no se trata de estar a favor o en contra de Don Quijote, como solía plantearse dilemáticamente el asunto, sino de asumir y apropiarse el talante de clasicidad, de lucidez y mesura, a un tiempo, del autor de la obra. «Para poner nuestro ánimo más allá de todo dualismo — clama Ortega - vino sobre la tierra Cervantes» ${ }^{87}$. No renuncia, sin embargo, al tema del heroísmo pese a las connotaciones idealistas del término, pero lo cambia también de signo al proyectarlo sobre la vida cotidiana. Todo hombre lleva en sí «un héroe muñón», al que hay que liberar y dejarlo ser frente a «una caterva de instintos plebeyoss ${ }^{88}$. Ortega coincide con Unamuno en que «la raíz de lo heroico hállase, pues, en un acto real de voluntad» ${ }^{89}$, pero ahora se pone cl acento en el carácter formal de esta "real voluntad», a diferencia de la ensoñación o el deseo, y no tanto en el contenido ideal del personaje clegido. Lo que importa, pues, es la autenticidad del acto y su originalidad práctica al apartarse de

\footnotetext{
${ }^{*}$ Del sentimiento trágico de la vida, OC, VII, 287.

OC, IX, 240.

* OC, IX, 249.

Del sentimiento trágico da la vida, OC, VII, 283.

Meditaciones del Quijote, OC, I, 326.

* Idem, 394-5.

Idem, 392.
} 
la inercia y la costumbre. La actitud heroica no estriba tanto en la tensión entre facticidad e idealidad, ser y deber ser, como pretendía Unamuno, sino entre originalidad y presión social. El héroe se quiere a sí mismo porque quiere ser un "sí mismo", un yo personal, en fidelidad a su tiempo y su circunstancia, pero sobre todo, a la honda exigencia o tarea que brota de su ser. Lo decisivo es encontrar, en cada caso, esta vocación que responda conjuntamente a la demanda de las circunstancias y a la exigencia más originaria del propio ser. La vocación queda descargada de todo sentido religioso trascendente, al igual que se desmitifica la hazaña heroica al desenmascarar, por abstracto e incontinente, el espíritu quijotesco de la utopía. Frente al heroísmo trágico surge así un nuevo heroísmo, al que cabe llamar jovial o lúdico, siquiera sea porque exalta los valores específicos de la creación. En lugar de la hazaña Ortega prefiere hablar de la aventura. Mientras que la hazaña aparece ligada al deber ser utópico, y, por tanto, a la experiencia de la libertad como conflicto trágico con el mundo, en la aventura habla más bien el poder-ser y la comprensión de la vida como un ensayo de posibilidades. «Quien no pueda lo que quiere/que quicra lo que puede» - repite Ortega citando una norma de Leonardo da Vinci- ${ }^{90}$. He aquí el talante de la clasicidad. El idealismo ético a lo quijotesco se compromete con hacer el poder de lo que se quiere, sin reparar en su posibilidad interna, porque no le guía el instinto de la posibilidad, y menos aún el de la realidad, sino el respeto venerativo a lo ideal y la creencia en su místíco cumplimiento. Frente a este morboso y patético desgarramiento Ortega propone, en cambio, como régimen de salud, querer el poder, o lo que es lo mismo, querer la posibilidad como método para la afirmación y confirmación del propio poder. Pero querer la posibilidad no implica el abandono de los ideales, sino su recusación como valores absolutos, a la par que el rodeo táctico para hallarles oportunamente su lugar y su hora, en el orden abierto del ser, pues «una de las dimensiones del mundo es la virtualidad e importa sobremanera que aprendamos a andar por él» ${ }^{91}$. El espíritu de aventura es el modo de participar lúdica y creadoramente en la fermentación virtual del mundo.

Ahora bien, ésta es precisamente la actitud de clasicidad que adopta Cervantes. Ortega la compendia en una sola palabra: alcionismo. Alción —el pájaro que anida en los días de calma, entre las tormentas, como un signo de nueva vida - es el símbolo orteguiano de la serenidad y la jovialidad, el temple de la alegría creadora, que no se rinde ante las dificultades pero tampoco se entrega a la orgía romántica del entusiasmo. El estilo alciónico cervantino encarna en la ironía liberadora, que se burla de toda exageración y ademán patético, de la exasperación trágica del dualismo. Su burla, por otra parte, no es desabrida y ácida, sino que está llena, como el humor, de ternura por aquello mismo que trata de relativizar. No es una burla aniquiladora sino

* En tomo a Galileo, OC, V, 89.

9) OC, II, 142. 
comprensiva. En otras palabras, Cervantes juega a la integración y en modo alguno a la confrontación de los contrarios, que Unamuno ve en el quijotismo. En un momento decisivo de Meditaciones del Quijote nos previene Ortega contra el riesgo de unilateralidad, que nos amenaza siempre en la cultura, por la acentuación exclusiva y excluyente de la idealidad o de la materialidad, del sentido o la nuda facticidad, que son los dos polos integrantes de la realidad. «Si la idea triunfa, la materialidad queda suplantada y vivimos alucinados. Si la materialidad se impone $y$, penetrado el vaho de la idea, reabsorbe ésta, vivimos desilusionados" ${ }^{92}$. En evitar este falso dilema, en encontrar el régimen fecundo de la calma y la reflexión en medio del fragor de los antagonismos consiste el alcionismo de Cervantes. Y era preciso, según Ortega, que este estilo mental se expresara en el género literario de la novela, porque en ésta se equilibra, por así decirlo, el régimen de to ideal y lo real. Este régimen de equilibrio es precisamente el clima alciónico de la libertad. Ni desmoralización ni alucinación. Ser libre es ser capaz de encarar la realidad sin autoengaño, pero también sin claudicaciones; aceptar la realidad inmediata, pcro intentar salvarla o reabsorberla en su sentido. Si El Quijote es un evangelio de salud para un pueblo desmoralizado, que había «querido demasiado», segín la bella expresión de Nietzsche, lo es, según Ortega, en la medida en que nos evita tanto la ilusión como la resignación, porque se opone con la misma energía al espíritu utópico como al escéptico, las dos almas que había dejado trágicamente enfrentadas Unamuno.

5.3. Pero ies posible - cabe imaginar que preguntara Zubiri - ensayar creadoramente la posibilidad, al modo orteguiano, si antes no se experimenta cn la realidad misma?, ino encierra el espíritu lúdico de la aventura todavía un cierto regusto idealista? Ciertamente, en la cuestión del quijotismo Zubiri no tuvo ocasión de tomar partido, pues posiblemente se tratara para él de una polémica superada ya por el curso de los acontecimientos. Pero sí, en cambio, en el problema de fondo que le subyace, acerca de la fermentación de lo real en lo posible y la consiguiente reinserción de lo posible $\mathrm{cn}$ el orden trascendental del mundo. Éste era el tema medular de la praxis como descubrimiento y apropiación de lo posible por parte de una realidad abierta y «realizanda» como la del hombre. No basta, por otra parte, con abrir un ancho horizonte de posibilidades si no se cuenta con el haber necesario para llevarlas a cabo. De ahí su intento de completar la praxis orteguiana en este punto con una filosofía de la historia de signo ontológico. Es preciso reconocer que en el análisis del concepto de posibilidad Zubiri brilla con luz propia, inflcxionando la herencia orteguiana y heideggeriana e introduciendo matices y precisiones que habían escapado al análisis existencial. La categoría de posibilidad significa aquí, conforme a la expresión castellana que menciona Zubiri, ser «un hombre de posibles» o que «tiene posibles». Con cllo se quiere indicar no sólo que tiene ante sí un ancho horizonte de posibilidades, sino que cuenta

\footnotetext{
"2. Meditaciones del Quijote, OC, 1, 386.
} 
con el haber necesario para llevarlas a cabo. La posibilidad es tanto aquello que se puede hacer como aquello con que se puede hacer lo que se puede. En el primer sentido la posibilidad es el objetivo del poder; en el segundo, su recurso o posibilitación: «Estas posibilidades nos descubren las cosas como instancias para forjar, para elaborar nuestra personalidad, y como recursos de los cuales disponemos justamente para hacer nuestra personalidads ${ }^{93}$. Esta nueva actualidad, que reciben las cosas en cuanto punto de apremio y de apoyo, a la vez, al poder humano es justamente la posibilidad. Pero no basta con que las cosas se pongan al alcance del poder, si éste mismo no ha madurado históricamente en orden a poderlas alcanzar. Se diria, por tanto, que la posibilidad es a una inherente al poder que puede como a las cosas con que se puede, y en esta unidad intrínseca consiste el poder posibilitante. Como precisa Zubiri, «como recursos, las cosas y la propia naturaleza no son simples potencias que capacitan, sino posibilidades que permiten obrar» ${ }^{94}$. Ahora bien, esta actualidad no está dada por naturaleza; aunque fundada en la nuda realidad, requiere de un devenir de actualización que es precisamente la historia. En consecuencia, mientras potencia y facultad pertenecen al orden natural del poder, la posibilidad, en cambio, se genera en el mundo histórico. O dicho en otros términos, las potencias y facultades se transmiten por gencración; las posibilidades, por tradición, es decir, merced al acarreo del haber colectivo que se produce en la historia. La historia es así, formalmente hablando, un proceso de entrega de posibilidades, y en cuanto tal un proceso de posibilitación, pues no todas las posibilidades son simultáneas, sino que a unas se accede viniendo de la previa realización de las otras, tras las otras, es decir, en un devenir de actualización. El fruto de este devenir constituye el haber histórico de la tradición.

Pero, sobre todo, la historia es básicamente para Zubiri «un proceso de capacitación». Con este nuevo teorema pasamos de la historia modal a la historia dimensional, esto es, de la historia como un modo im-personal de acopio y entrega de posibilidades a la historia como una di-mensión personal, es decir, en cuanto un acontecer que di-mensiona, esto es, mide, y a la vez potencia a la persona en su personalidad. Se consigue así una nueva cualificación de la potencia, que la dispone en el orden mismo de su futura posibilitación. Hay, pues, un círculo o ciclo, como subraya Zubiri, entre capacidad, posibilidad y capacitación ${ }^{95}$, pues toda actualización de posibilidades refluye sobre la potencia aumentando su capacidad. Vista, pues, a esta nueva luz, la historia no cs un proceso de maduración ni de desarrollo, sino de capacitación de los individuos en orden al incremento de su propio poder. En este sentido, como afirma Zubiri, «es realización radical. Es producción del ámbito mismo de

3stnciura dinámica de la realidad, Alianza Editorial, Madrid, 1989, pp. 248-9.

* Naturaleza, Historia, Dios, op. cit., 311.

95 a dimensión histórica del ser humanom, en Realitas, Socicdad de Estudios y Publicaciones, Madrid, 1874, 1, 54. 
lo posible como condición de lo real: es hacer un poder. Por eso es cuasicreación» ${ }^{96}$. La expresión castiza «hacer un poder», como otras rehabilitadas filosóficamente por Zubiri, encierra muy certeramente la intuición metafísica de lo que es el poder por antonomasia en cuanto principio. El poder no está dado por naturaleza, salvo sus bases psico-orgánicas, sino que se hace históricamente, esto es, se alcanza en un devenir de actualización de posibilidades. Como se ha anticipado, el poder no debe entenderse como la nuda actuación de una potencia natural, ni siquiera como el ejercicio y el hábito consecucnte de una facultad, sino como el incremento interno, pro-gresivo e in-tensivo de una capacitación. Por retomar de nuevo el tema abierto del heroísmo, tal vez pudiera decirse que en este poder activo de capacitación y realización de sí radica para Zubiri la figura del héroe.

Es hora ya de concluir estas páginas miniadas por un ensayo comparativo entre modelos radicalmente heterogéneos. Dada la complejidad del panorama, apenas esbozado, acabarlo con una reflexión crítica desborda a todas luces por su complejidad la limitada oportunidad que aquí se me brinda. Me ahorro, pues, cerrarlo sumariamente con un juicio ponderativo, aun cuando toda comprensión genuina encierra en sí un momento judicativo acerca de la cosa misma que está en cuestión. Graciosamente prefiero acogerme a la consigna arangureniana de «comprender antes que juzgar», aunque él se refería, claro está, al juicio inquisitorial, que él quería desterrar de una vez por todas de la vida española. Parece ocioso, sin embargo, advertir que entre estos tres modelos no se da una progresión dialéctica, como si cada uno se levantara sobre las ruinas de su adversario, integrándolo en una conccpción de más alto nivel. Más que la superación dialéctica habría que aceptar aquí el esquema diltheyano de la disputa permanente entre plurales imágenes del mundo, que por la heterogeneidad radical de sus premisas y actitudes no se dejan reabsorber en una unidad superior. No quiero renunciar, sin embargo, al momento hermenéutico de la aplicación. En este caso tal tensión forma parte de nuestra conciencia filosófica contemporánea y puede convertise, asumida creadoramente, en una fecunda inspiración para abrir nuevos caminos de pensamiento.

${ }^{96}$ Idem 55 . 